\title{
Mosaics of the Hispanic Meseta Norte: Phases, Officinae,
} Artistic Taste

\author{
Hispanik Meseta Norte'ninMozaikleri: Evreler, Atölyeler, \\ Sanatsal Yönü
}

Fernando REGUERAS - Caridad SAN JOSÉ*

(Received 01 December 2016, accepted after revision 21 July 2017)

\begin{abstract}
About 400 mosaics are known in the Meseta Norte (today, Comunidad Autónoma of Castilla y León), with chronological variants, most of them of the $4^{\text {th }}$ and $5^{\text {th }}$ centuries; with stylistic variants, geometrical topics in preference to figurative themes; with topographical variants, predominantly rural findings against urban findings; and with technical variants, exceptionally sectilia, only one case of signinum and the rest, tessellati. We know nothing about the mosaic workers, just the signature of one who worked in the Baths of La Olmeda (Palencia): Sil [o]. However, stylistic, morphological, or material concordances allow us to suspect the existence of workshops, which usually operated in regional areas. Surely the former ones were Italic workshops serving people of that origin (opus sectile and opus signinum, Asturica Augusta). Almost two centuries after another officina is documented, known as Clunia-Uxama-Asturica, because it worked in these three cities, and their consequences are still tracked in the late third century in certain domus of the above-mentioned cities. The great mutation of Roman mosaic in the Mesetas occurred in the fourth century with the spectacular display of villas, unparalleled in Hispania. Serving these new customers a large number of workshops was developed, for instance, the designated one as the NO peninsular workshop, which worked in the provinces of León and Zamora; the so-called one as Prado-Almenara workshop, because of its presence in these villas from Valladolid, and also in La Valmuza (Salamanca) where another workshop took part closely linked to some villas from La Mancha. Finally, the Cuevas-Valdanzo workshop, whose taste for the aniconism links these villas of Soria with other more western ones.
\end{abstract}

Keywords: Meseta Norte, Castilla y León, urban and rural phases, Aniconism, Orientalism.

$\ddot{\mathrm{O} z}$

Meseta Norte'den (günümüzde Castilla y León - Comunidad Autónoma) kronolojik olarak geniş bir zamana yayllan fakat çoğunluğu 4. ve 5. yüzylla tarihlenen 400 kadar mozaik bilinmektedir. Bu mozaiklerde; geometrik desenlerin figüratif desenlere tercih edilmesi gibi çeşitli stilistik varyasyonlar, kırsal unsurların kentsel unsurlara göre daha ă̆ırlıkta olması gibi değişik coğrafi özellikler görülmektedir. Teknik olarak da mozaiklerin çeşitlilik gösterdiği söylenebilir; mozaiklerin büyük bir çoğunluğu tessellatum tekniği ile yapılmışken, istisnai olarak sectile ve sadece bir örnekte signinum görülmektedir. Sadece La Olmeda Hamamları'nda (Palencia) çalışan birinin isminin Sil [o] olması dışında mozaik yapımında çalışanlar ve ustalar hakkında bilgi bulunmamaktadır. Bununla birlikte, üslup, biçim ya da malzeme benzerlikleri, bölge içinde faaliyet gösteren atölye çalışmalarının varlı̆̆ı konusunu gündeme getirmektedir. Elbette eski atölyeler, İtalik kökenli olup bölgedeki insanlara hizmet ediyordu (opus sectile ve opus signinum, Asturica Augusta). Çalıştı̆̆ ş̧ehirlerin isimlerine ithafen Clunia-Uxama-Asturica olarak bilinen diğer bir atölyenin belgelenmesinden iki yüzyll sonra yani 3. yüzyılda bu atölyenin etkileri yukarıda bahsi geçen kentlerin evlerinde hala izlenebilmektedir. Mesetas'taki Roma mozaiklerinde görülen büyük değişim 4. yüzyılda Hispania'da eşi görü̈lmeyen muhteşem tasvirler aracıllğıyla gerçekleşmiş̧tir. Yeni müşterilere hizmet vermek üzere pek çok atölye faaliyet göstermeye başlamıştır. Örneğin

\footnotetext{
* Fernando Regueras, C. E. B. “Ledo del Pozo”. E-mail: fernandoregueras@gmail.com Caridad San José, C. E. B. “Ledo del Pozo”. E-mail: caridadsanjose@gmail.com
} 
Leon ve Zamora Bölgeleri'nde çalışan NO olarak isimlendirilen Ada atölyesi ile Vallodolid'den ve La Valmuza'daki villalarda yaptı̆̆ mozaiklerden tanınan Prado-Almenara Atölyesi ve La Mancha'daki villalardaki işleri ile bilinen bir başka atölye gibi. Son olarak Soria villalarından ve daha batıdaki örneklerden bilinen çalışmalarıla ve anikonizm tercihiyle bilinen Cuevas-Valdanzo atölyesi gösterilebilir.

Anahtar Kelimeler: Meseta Norte, Castilla y León, kentsel ve kursal evreler, Anikonizm, Orientalizm.

We are going to speak about the mosaics of the Hispanic Meseta Norte, highlands (700-800 m on average), a bastion well shaped by mountainous edges (The Cantábrica range in the $\mathrm{N}$, the Ibérica range in the $\mathrm{E}$, the Central range in the $\mathrm{S}$, and abrupt peneplains in the $\mathrm{W}$ ), drained by the Douro river and its tributaries, with marginal aggregate ones in the NW (Sil Basin), in the E and NE (Ebro Basin), and in the $\mathrm{S}$ (Tagus Basin). This is an extensive territory $\left(94.222 \mathrm{~km}^{2}\right)$, bigger than Portugal, at the present configured by the Comunidad Autónoma of Castilla y León (Fig.1), with 9 provinces (Ávila, Burgos, León, Palencia, Salamanca, Segovia, Soria, Valladolid and Zamora). In Roman times it was divided in two large Conventus Iuridicii: the Conventus Asturicensis, capital Asturica Augusta, origin of the Kingdom of León, in the W, and the Conventus Cluniensis, capital Clunia, origin of the County of Castile, in the E. With less remarkable personality, the old territory of the Vettones in the SW (provinces of Salamanca, the south of Zamora and the west of Ávila) formed part of the

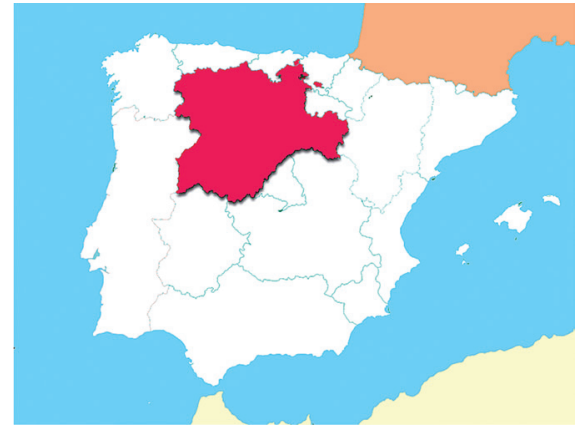

Figure 1

Meseta Norte (or Castilla y León) into Iberian Peninsula.

\section{Conventus Emeritensis.}

About 400 mosaics $^{1}$ are known, with a great territorial asymmetry, because of the origin, technique, theme, and chronology. More than $60 \%$ of the exemplars are in the $\mathrm{E}$ of the Autonomous Community (provinces of Soria and Burgos), and to a lesser extent, Palencia, in the centre of the Douro Basin, a situation that is, however, rather random. About the origin, the bulk comes from rural deposits (villae), and less than $10 \%$ from cities, almost all of them from Asturica, Uxama, and especially Clunia. The difference is still greater in technical terms: only one mosaic of opus signinum is known, less than 10 mosaics of opera sectilia, which should not be confused with simple marmoreal paving stones, and the rest are tessellated. The disparity is similar in theme, and chronological terms: the characteristics which as a whole define the Douro mosaics are their massive aniconism and late dating, as we are going to see later.

Regarding the phases of the mosaic in the Meseta Norte, there are two moments:

- a first urban phase due to its development mainly in the cities and highimperial chronology, coinciding with the Roman military occupation, municipalization and domestic reforms of their houses, between the $1^{\text {st }}$ $3^{\text {rd }}$ centuries AD (Fig. 2).

- a second rustic phase that is manifested mainly in the great late antique villae, coinciding with the historical experience of the family of Emperor Theodosius, born in Cauca (Segovia), in its almost one century of documentation between the $4^{\text {th }}$ and $5^{\text {th }}$ centuries AD (Fig. 3) (Regueras Grande 2007 and 2013).

1 Many of the pavements have been published in the Corpus de Mosaicos de España (CME): López Monteagudo, Navarro Sáez and Palol Salellas 1998 (Burgos); Neira and Mañanes 1998 (Valladolid); Blázquez et al. 1993 (León); Blázquez and Ortego 1983 (Soria); Blázquez et al. 1989 (Museo Arqueológico Nacional). Outside the Corpora: Regueras Grande and Pérez Olmedo 1997 (Salamanca). Regueras Grande 1990 and 2009 (Zamora). Palol 1963, Pérez González 1987, Cortes Álvarez de Miranda 1996, García Guinea 2000, Regueras Grande 2012, Abásolo 2013 (Palencia). Lucas and Viñas 1977, Regueras Grande 2010 (Segovia). Mariné 1995, Moreda Blanco and Serrano Noriega 2012 (Ávila). There are also some synthesis works: Torres Carro 1990, Regueras Grande 2007 and Regueras Grande 2013 
Figure 2

Main Roman cities of

Meseta Norte.

Figure 3

Dispersion of main Roman villae in Castilla y León.
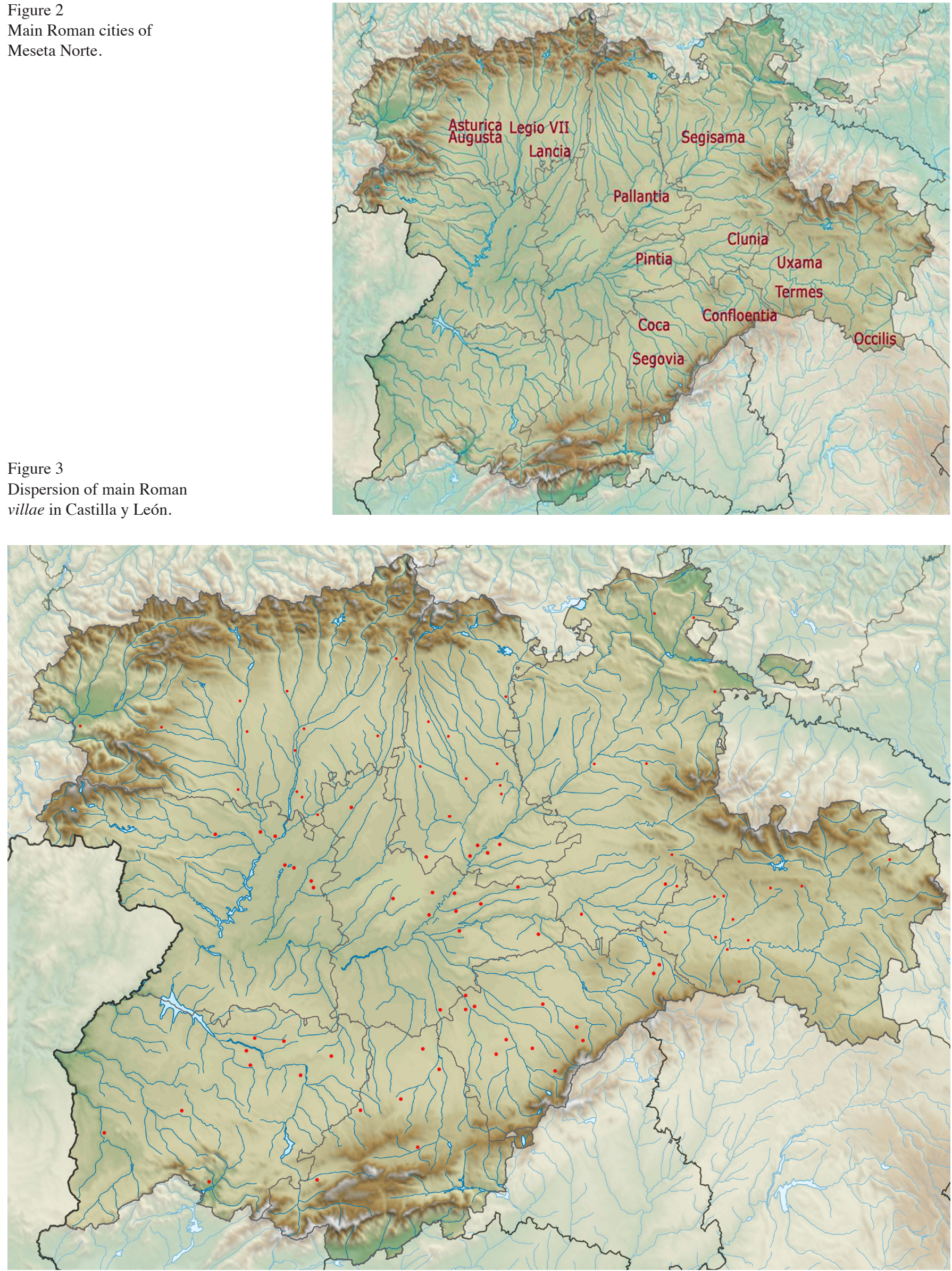

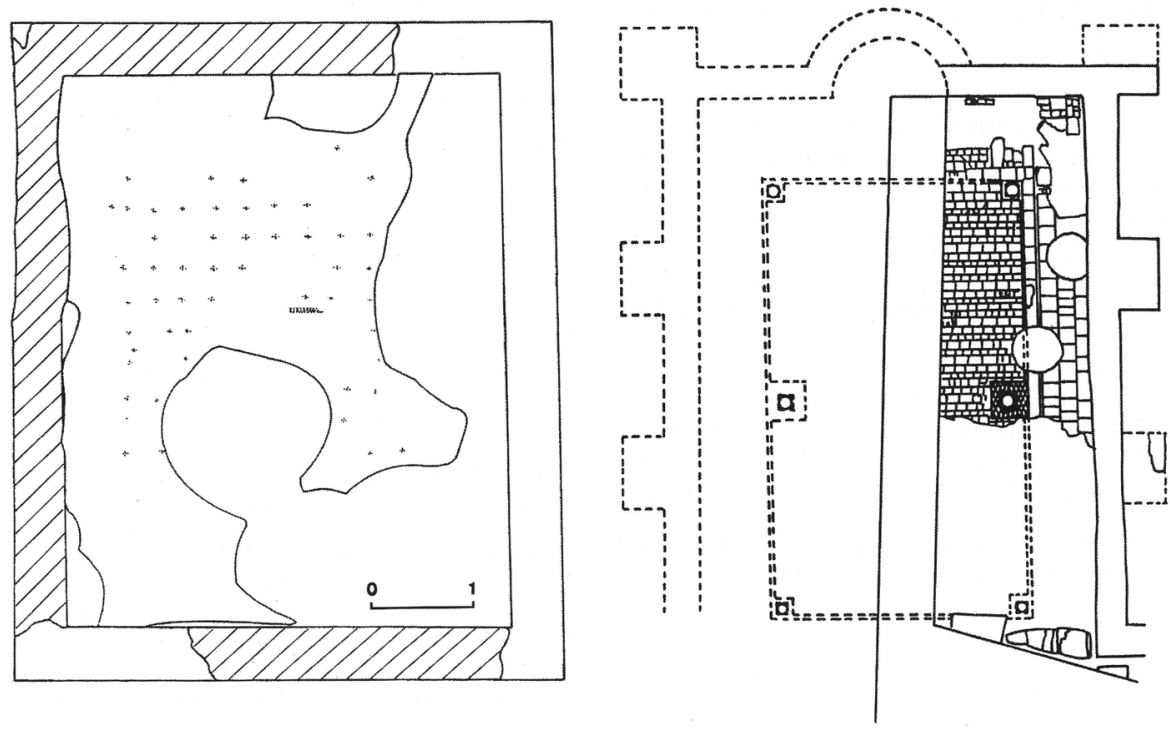

One of the first mosaics of the Douro Basin is a paving of opus signinum (Fig. 4) of a domus of Astorga (Regueras 2002: 37-11), decorated with bichrome crosses, and it dates in the middle of the $1^{\text {st }}$ century AD, unicum because of its geographical location, so the opera signina are strictly circumscribed in the $\mathrm{E}$ and $\mathrm{S}$ of Hispania. The appearance of this type of floors is associated with the presence of Italic immigrants, who would try to surround themselves with domestic equipment similar to that of their native environment, and in a second moment with acculturated natives eager to emulate the tastes of the new ruling class.

In Asturica Augusta it is also documented the oldest opus sectile (Fig. 5) in the region, in Julio-Claudian period, paving the Aedes Augusti, political centre of the new capital of the Conventus. Luxurious (marble), but austere (bichrome), it derives from a simple Italic model of modular writing, and it is the monumental consecration of the first profits of the gold exploitations begun towards the end of reign of Augustus. Slightly posterior it is another domestic tapestry, superimposed on the aforementioned opus signinum during a reform carried out in the middle of the $1^{\text {st }}$ century, and a new sectile that upholstered the frigidarium of the so-called "Domus del gran peristilo", at the beginning of the $2^{\text {nd }}$ century. Both of them have disappeared.

With no apparent connection with Astorga, two other parietal sectilia of the Flavian period are known in Clunia (Burgos), a basilica of the forum and a triangular room of the macellum, with vegetal themes and vegetal composition (López Monteagudo et al. 1998: 41-85), and another in a domus of Uxama (Soria) (Blázquez - Ortego 1983: 52-54), dated in the first half of the $2^{\text {nd }}$ century, also with imported marbles.

The sectile should have continued to be used, but there was practically no trace until the $4^{\text {th }}$ century in the transept of the aula trichora of the villa of Rioseco de Soria, and especially in the missing ones of Las Pizarras in the vicinity of Cauca (Segovia), where more than 20 kinds of marbles have been registered.

We do not know when the opus tessellatum appears in the Douro Basin. If we accepted the dating of his archaeologist, Tiberian epoch, (Argente et al. 1990: 37-42), the first example would be (with intrusions in red and black colour) a large monochromatic mosaic area of the balneum of a domus, in the $\mathrm{N}$ of the Forum of Termes with strange planimetry, a rectangular central room and other two preserved flanking circular rooms. It has come to be interpreted as an
Figure 4

Outline of opus signinum from Asturica Augusta.

Figure 5

Opus sectile of Aedes Augusti from Asturica Augusta.

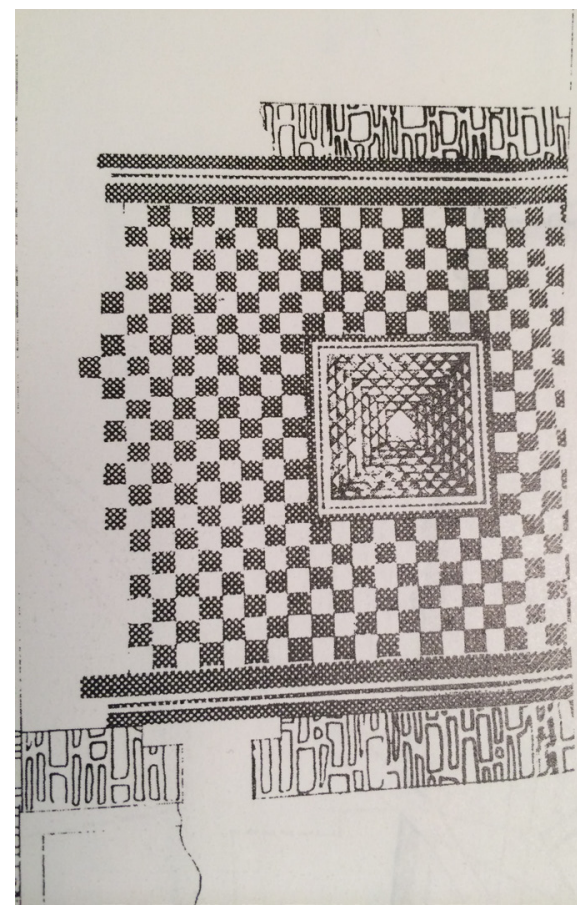

Figure 6 Termas Mayores of Asturica Augusta. 


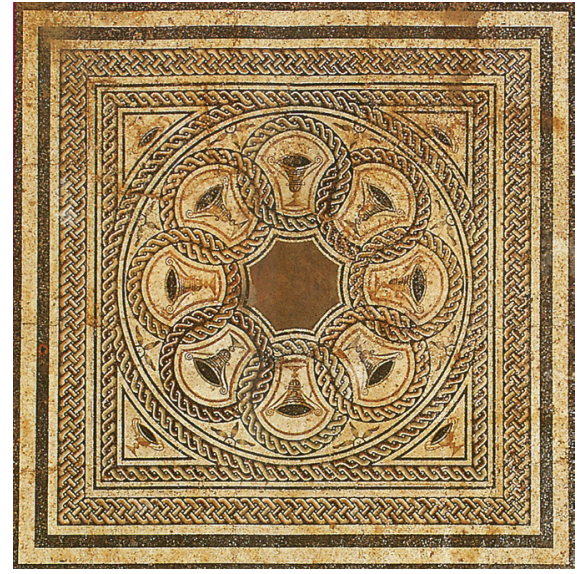

Figure 7

Mosaic of the Kraters of Clunia.

Figure 8

Mosaic of Quinta Romana of

Uxama.

Figure 9

Mosaic of Casa del oso y los pájaros of Asturica Augusta.

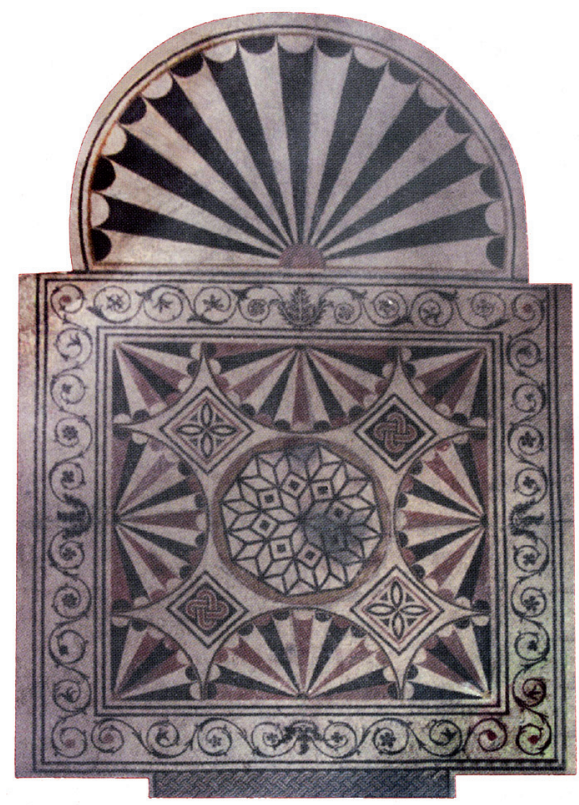

Figure 10

Mosaic de las Veneras of Clunia.

Museo Arqueológico Nacional (Madrid).
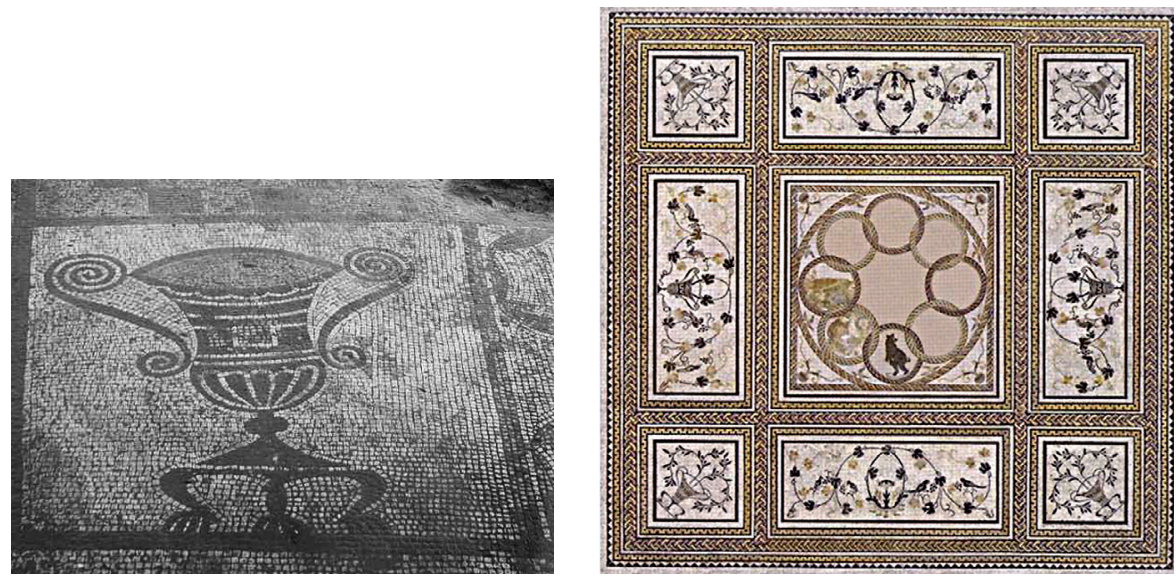

initiatory sauna of Celtiberian tradition. It presents stylistic problems similar to the enormous black \&white pavement of Las Molleras in Salinas de Rosío (Burgos), for some people it is of the $1^{\text {st }}$ century, and for others it is late and of equally complicated functional interpretation.

From the end of the $1^{\text {st }}$ century until the $4^{\text {th }}$ century (Clunia) several officinae work here, in Uxama, and in Asturica. They maintain until the end the attachment to the Italic tradition in schemes to compass (Fernández Galiano 1980a) and squares of bands, and the taste for the bichromy without renouncing the colour. A first moment is manifested in the work of officina/officinae that intervened in the Pequeñas Termas, and Termas de Los Arcos I and Los Arcos II of Clunia at the end of the $1^{\text {st }}$ and $2^{\text {nd }}$ centuries, perhaps also in the denominated Casa Basilica of Uxama and Termas Mayores of Asturica (Fig. 6).

The consolidation of these teams takes place at the end of the $2^{\text {nd }}$ and $3^{\text {rd }}$ centuries with the workshop called Asturica-Clunia-Uxama, the most important cities of the territory, united through Iter 27 of the Antonine Itinerary between Asturica and Caesaraugusta. It is always an officina of Italic tradition in its cartons, attachment to the bichrome tradition despite the use of the colour, use of linear scrolls associated with birds and some identical formal and syntactic motifs: kraters, split hexapetals, geometric borders and link of panels. The connections between the mosaic of the kraters of the Casa $\mathrm{n}^{\circ} 3$ (Fig. 7) and the Casa Triangular of Clunia, the mosaics of the Quinta romana of Uxama (Fig. 8) and the Casa del Oso y de los Pájaros of Asturica are incontestable (Fig. 9). It is possible to establish links between this workshop and some other urban mosaics dated in the $2^{\text {nd }}$ and $3^{\text {rd }}$ centuries: $e$. g. the one that carpeted two tabernae near the Foro Flavio de Termes, with the theme of scrolls of acanthus populated with little animals, one of these recalls some mosaic of the Calle San Gil de Medinaceli (Occilis), where the scrolls of tendrils with pigeons and kraters, and the same meander of swastikas of Termes also appear. The presence, on the other hand, and design of the gryphus in one of the decorated bands of the tessellated of Occilis we have to relate it with the heraldic bichrome ones of Uxama, dated by Balil in the $2^{\text {nd }}$ century, and perhaps with those ones of the Seminario Conciliar of Tarazona (Zaragoza) of the same date.

At last, the schemes to compass in shape of a shell of segments are reiterated in Clunia, especially in the mosaic of the shells of Casa Taracena (Fig. 10) and in the strictest parallel, room no. 1 of the so-called "Basilica" of Uxama (Fig. 11) in reduced version and larger scale in the most colourful of the Plaza de San Pedro de Medinaceli. A later variant of this interest in compass (and segments) motifs is found in one of the few villae of the Meseta, Villabermudo, in the $\mathrm{N}$ 

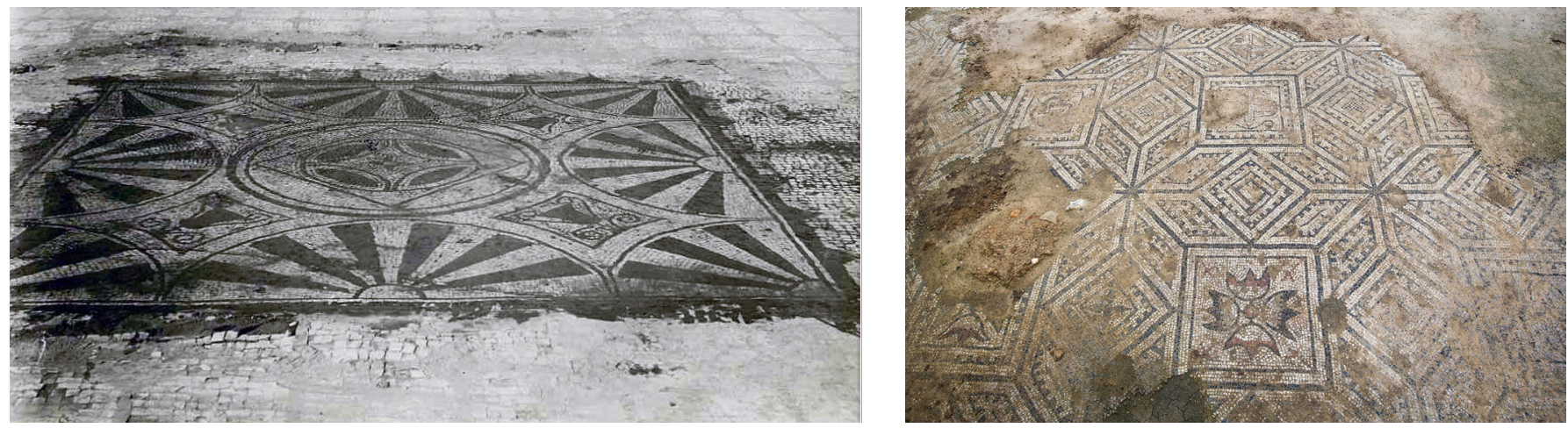

of Palencia, their mosaics have been dated in the $3^{\text {rd }}$ century, with parts in the Constantinian period: mosaic of Diana, mosaic of the exedra, and mosaic of the

Figure 11 kraters. Curiously it is a suburban villa, very close to Pisoraca, city of military origin as Asturica, the Legio IIII Macedonica was stationed there during the Cantabrian wars (Pérez González 1987: passim). The contacts between the three cities are not ended with these examples. Twenty years ago I already posed the affinity between the mosaic of the room no. 6 of the Casa Taracena de Clunia, and a fragment of mosaic of Uxama drawn by Loperráez in the $18^{\text {th }}$ century, with the same scheme: star of rhombuses determining large right squares and small ones with sharp point (AIEMA 367), with similar themes inscribed, which was then used by me to reconstruct vestiges of a pavement of Asturica the so-called "Casa del opus signinum" (Regueras Grande 2002, mosaic no. 6), one of the main houses of the city that opened to the cardo maximus. Fortunately, in April 2016, they were able to confirm his belonging to the west wing of a peristyle (Fig. 12). Some remains of the north wing also appeared, with the possible theme of panels framed by braids of three ropes, all of them maintaining the same attachment to the Italian tradition in the traces, even in the austerity and chromatic continence. The dating, well into the $3^{\text {rd }}$ century, is still the most reasonable.

Another officina, with the same formal and chromatic sensitivity, which operated on the same dates, made the mosaics of Pallantia (Palencia) and Segisama (Sasamón, Burgos), where the Legio IIII Macedonica was also settled, mansio between Asturica and Burdigala. Although the old scheme of octagons and crosses is used mainly in late times, with filler of geometric or vegetal motifs, our Castilian tapestries are ordered by mythological images: Gorgona and the Seasons (Pallantia) or by a marine character, perhaps Triton (Segisamo), apart from many other figurative coincidences (birds, marine animals, fulmina) (Fig. 13).

What it does look like a very important set, with very classic taste, are the mosaics excavated at the end of the $18^{\text {th }}$ century (Gómez de Somorrostro 1820: 215 225) in Los Mercados (Duratón), a place that today is often identified with the city of Confloentia. At least five mosaics are known, three of them were extracted, one of the Medusa, other one of the Annus and another of the Grape Harvest, its detailed description reminds us of Bacchus mosaic of Complutum. The configuration of this one also resembles that of the Seasons of Paradinas (Segovia) (Fig. 14) (Regueras Grande 2012: 288-293), showing a relationship between the mosaics on one side and the other one of the Central range, lands well connected by a via between Complutum, Duratón and Clunia, known in Islamic era, but surely with a Roman origin. Only the one of Annus is conserved, with so many spare parts that Balil considered it a contemporary pastiche. Blázquez (Blázquez et al. 1998b: 34) dates it in the $2^{\text {nd }}$ century. 
Figure 13

Mosaics of Pallantia (left) and Segisama (right).
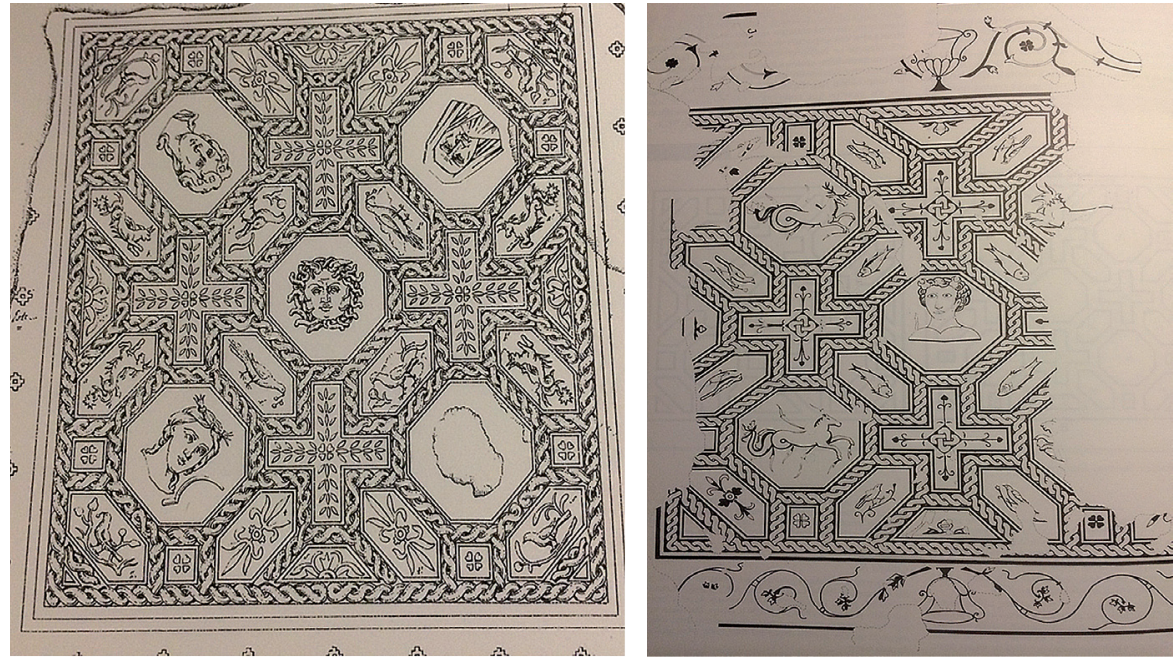

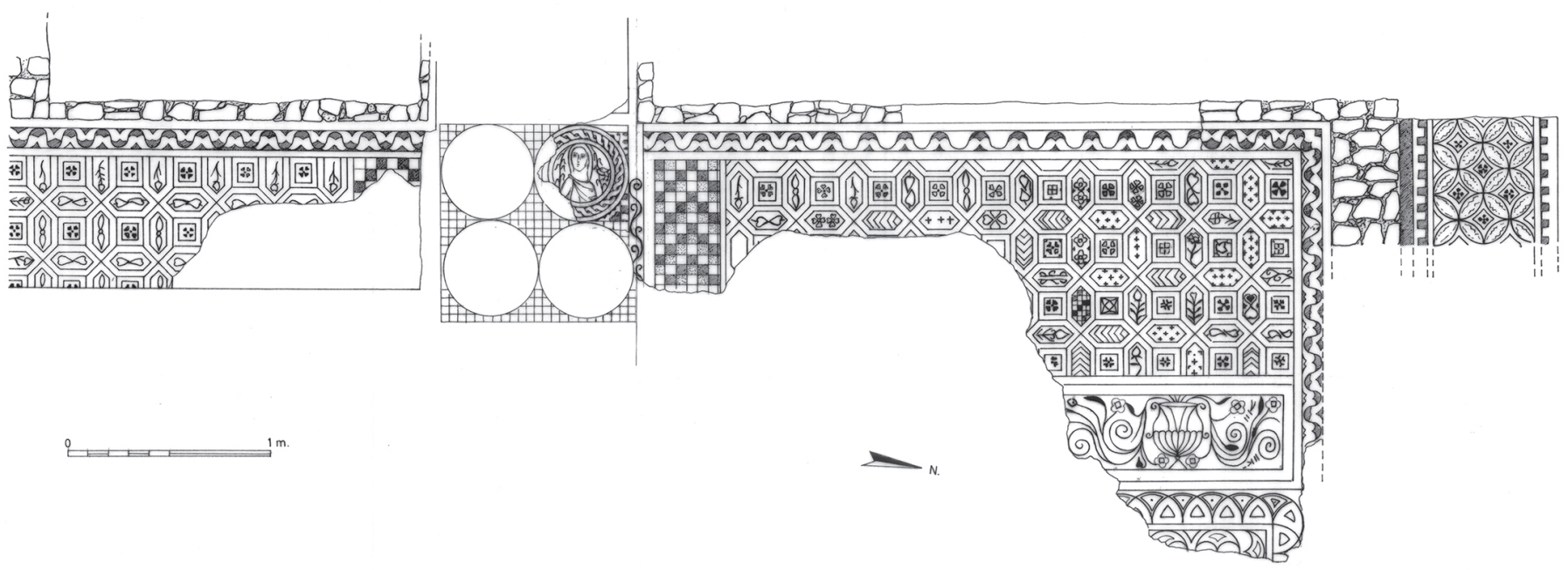

Figure 14

Season mosaic.

Paradinas (Segovia).
Despite the languor of the cities in the $4^{\text {th }}$ century, the mosaic did not disappear, but we know a few examples. In Clunia, a coin of Constantine in the rudus of the mosaic no. 4 of the Casa de Taracena leaves no doubt about chronological speculation (Fig. 15). In Leon, after almost 35 years of excavations, only a "representation of a sea full of algae and fish" (1884) from the baths under the cathedral is known, but all that remains is only a fragment of a water flower and a Cypraea clam, (Fig. 16) of the style of the so-called "NW workshop" (Regueras Grande 2015: 279-304). In Medinaceli, the mosaic of the Plaza Mayor (Borobio - Pascual 1998: 39-45) with its images of the winds and Ceres, seems a variation of the same motifs in the villa of Villares de Santervás del Burgo (Soria). Finally, in Segovia, some polychrome mosaic fragments from the Calle Judería (Martínez - Vilches 2015: 82-83) have allowed a recomposition of the scheme based on a mesh of rotating squares with birds and other inscribed geometric motifs, elements that could not be assigned to the $1^{\text {st }}$ and $2^{\text {nd }}$ centuries as their excavators do, rather to a late epoch.

The second phase of the Douro mosaics is developed in the $4^{\text {th }}$ century and the beginning of the $5^{\text {th }}$ century coinciding with its generalization in the villae. In the Late Roman Empire there was a concentration of property after the changes that took place during the tetrarch period, which resulted in the replacement of the old and frugal high-imperial installations with more pretentious and larger ones. This monumentalisation of the manor house is expressed through an arrogant 


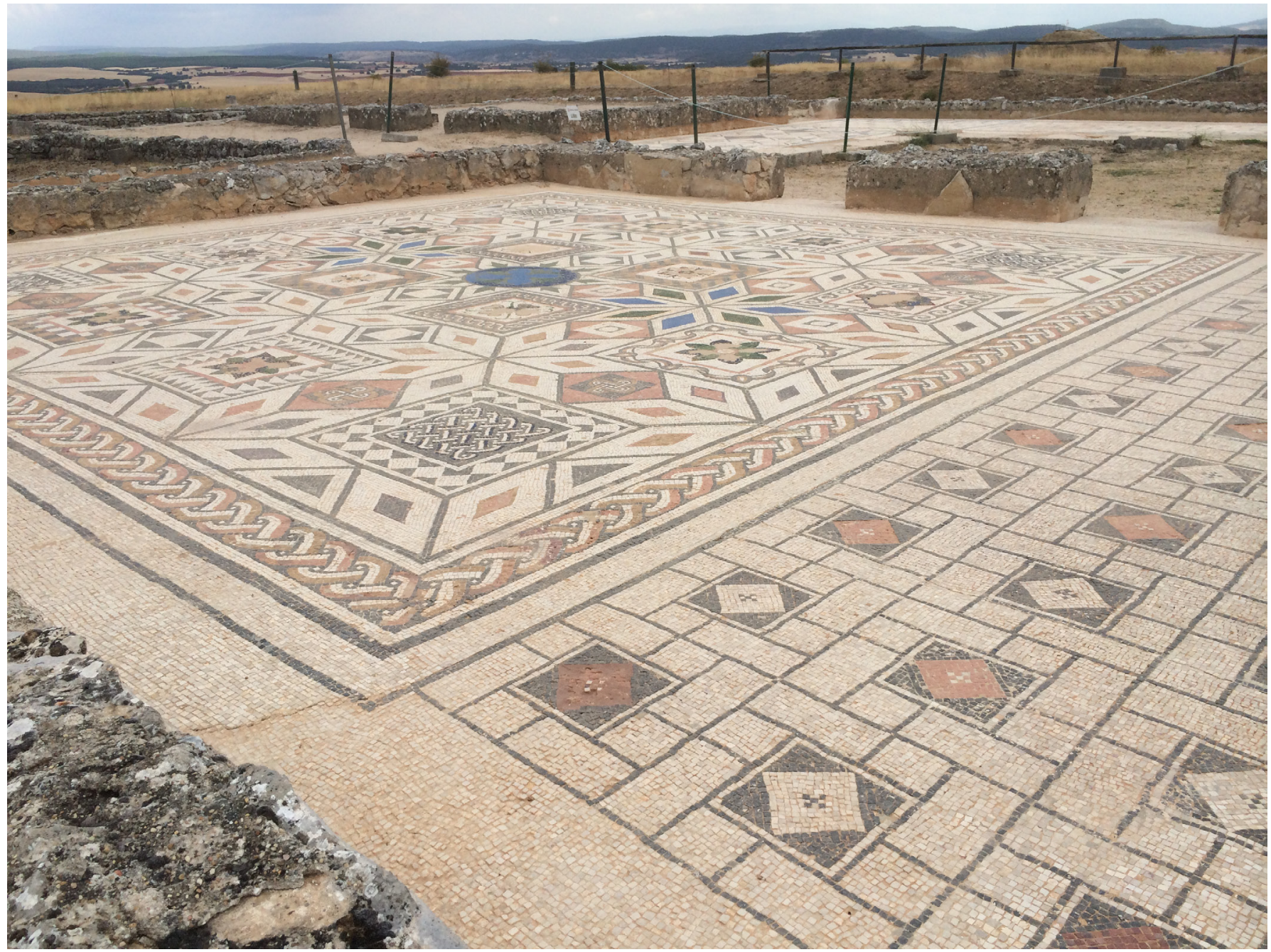

architecture (basilical and apse-shaped aulae) as in no other part of Hispania, and a luxurious ornamentation, of which only the mosaics are usually left.

We know a little about the owners of our villae, although the exceptional archaeological record of contorniates in the villae of Quintana del Marco (León) and La Olmeda (Palencia) (Cortes Álvarez de Miranda 1996: 59-78), emphasises their quality of elites. The story of the family of Emperor Theodosius, born in Cauca (Segovia), rich landowners from the father Flavio Theodosius until the cousins of his son Honorius, Didymus and Verinianus, who defended the rights of the legitimate monarch against usurpers and barbarians, coincides and documents almost a century, with the display of our villae in the $4^{\text {th }}$ and $5^{\text {th }}$ centuries. Unfortunately we lack of epigraphic testimonies on mosaics. An exception in this anonymous landscape could be the case of Cuevas de Soria (Soria) where they wanted to associate the Irrico, family of Celtiberian origin that is buried in the vicinity of the property, with analleged monogram (Fig. 17) that appears strategically repeated in several mosaics of the house. Another one that dresses one of the panels of the no. 3 carpet of the villa of Requejo (Santa Cristina de la Polvorosa, Zamora) is less firm. Due to its location and quality some images are perhaps their portraits: in the border of intertwined cornucopias that involves the Bacchus triumph of Baños de Valdearados (Burgos) there are two central busts, masculine and feminine, that if they were not the owners of the villa, it would make little sense (Fig. 18). In La Olmeda, also in a wide heraldic valence
Figure 15

Mosaic no. 4 of the Casa Taracena, Clunia (Burgos).

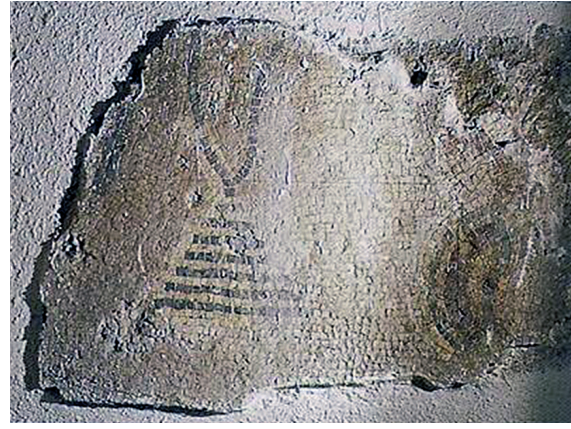

Figure 16 Cathedral Baths. León. 
Figure 17

Alleged monogram of the Irrico, (Cuevas de Soria, Soria).

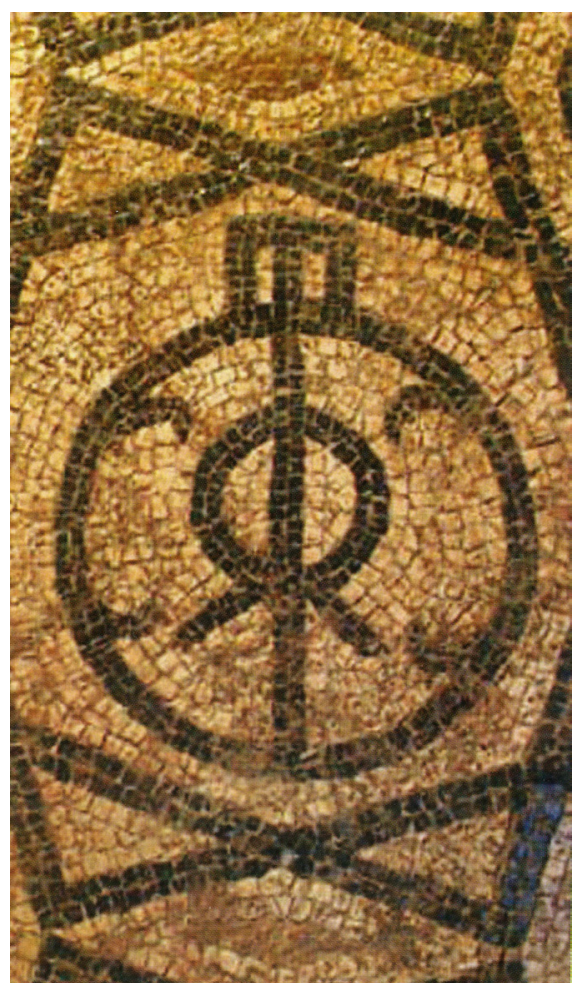

Figure 18

Domini of the villa of Baños de Valdearados (Burgos).

Figure 19

Triclinium with the Orpheus

Mosaic. Camarzana (Zamora).
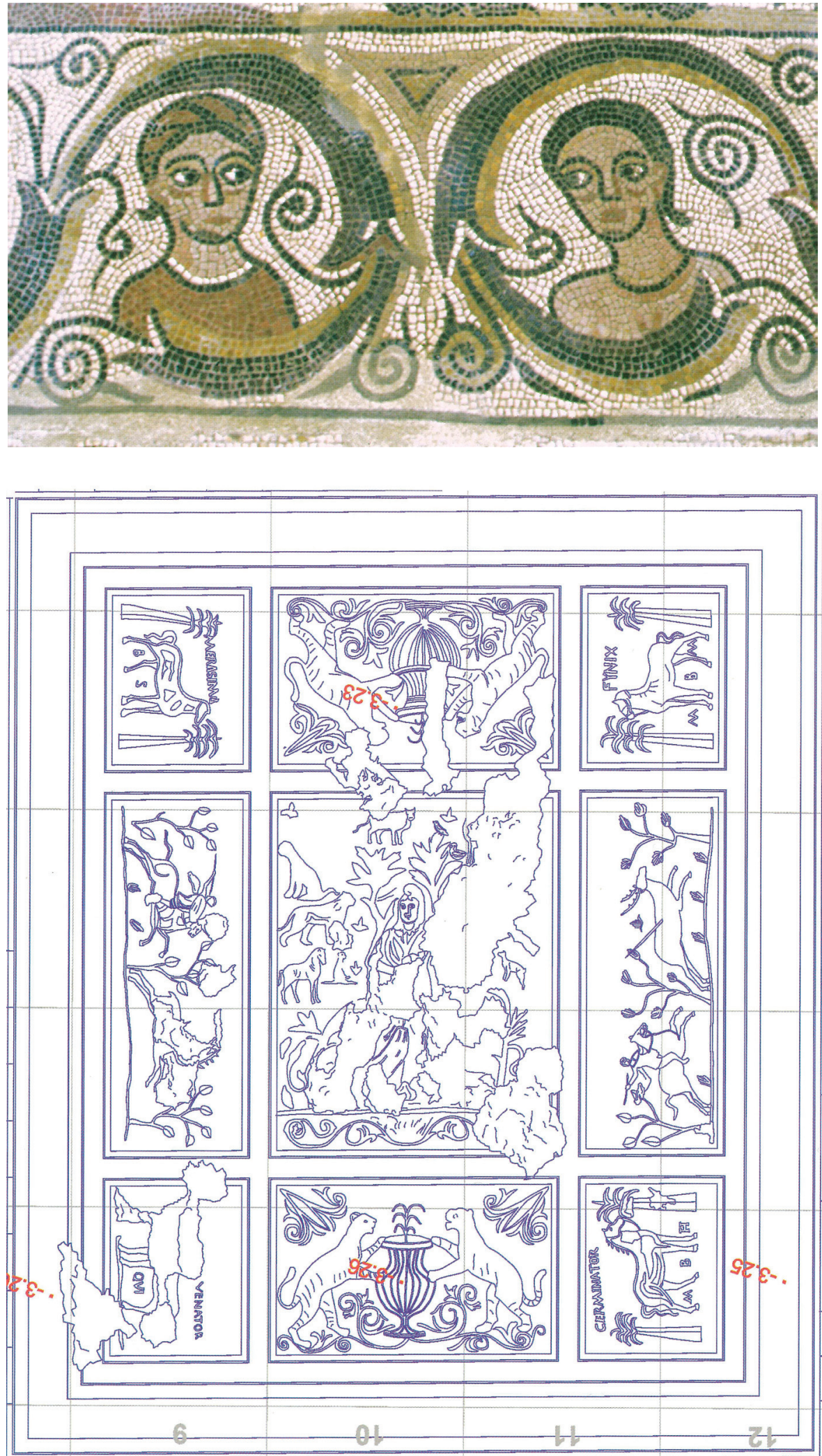

of the mosaic of Achilles, 18 male and especially female portraits of different ages are unfolded, undoubtedly the family saga of the dominus. It is also probable that some horsemen spearing their prey, such as the one of the threshold of the triclinium of Camarzana de Tera (Zamora) (Regueras Grande 2009), the other one disappeared from the villa of Campo de Villavidel (León), that one of 
the dismounted rider of the frigidarium of Dueñas (Palencia) next to his steed, or the other one that accompanies Atalanta and Meleager in Cardeñajimeno (Burgos), all of them could be the effigy of the owners of the mansion represented in one of their favorite activities. Their hunting tastes were well reflected in the mosaics, such as the hunt: Camarzana (Fig. 19), Cardeñajimeno, Campo de Villavidel, venationes (La Olmeda), or transFig.d from the myth: Diana the Huntress (Villabermudo -Palencia-, Prado -Valladolid); Bellerophon (Ucero-Soria-, Saelices - Salamanca); Atalanta and Meleager (Cardeñajimeno, San Pedro del Arroyo - Ávila). It is the same passion for the horses, which presides over the main rooms of the house: Aguilafuente (Segovia) (Lucas - Viñas 1977: 245), Camarzana; and they are sometimes transmuted into mythological horses, Pegasus without its wings of Almenara -Valladolid(Fig. 20), or the dominus takes his favorite foal on his golden ring (Quintana del Marco), or his horse presides over the large carpet of its balneum (Dueñas) (Palol Salellas 1963: pl. X).

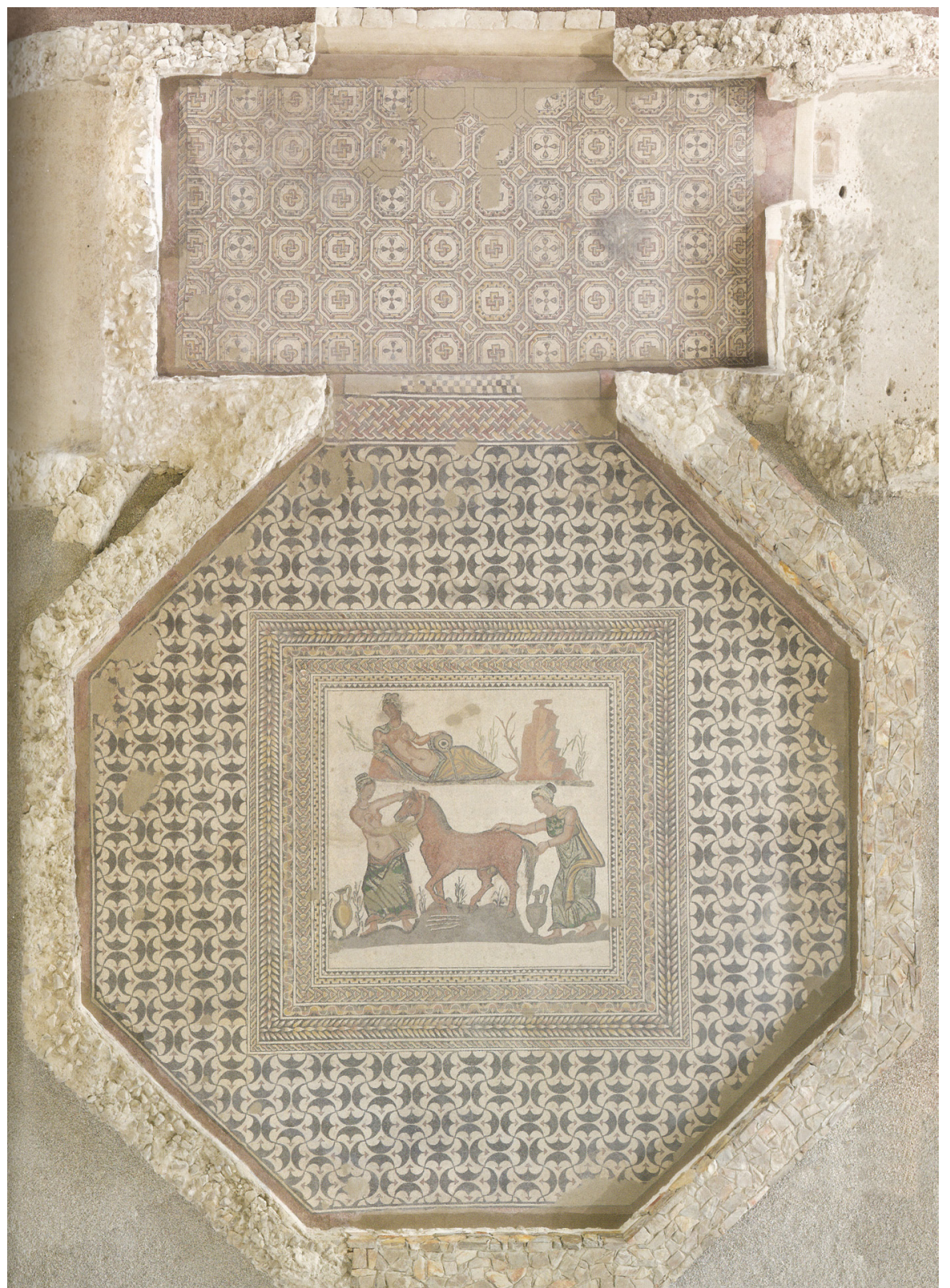


Figure 21

General plan of La Olmeda with the mosaics. After Abásolo 2013.
Adjusting now strictly to the mosaics, we do not know what relations could be between the old, high-imperial officinae and the new ones that usually work in the Late Roman Empire, but the bonds with the Galician area (NW workshop), Ebro Valley and above all the Meseta Sur (several officinae) are well contrasted. The lack of dating by archaeological methods remains a burden to establish a precise evolution during the $4^{\text {th }}$ and $5^{\text {th }}$ centuries, with very imprecise extreme margins.

The aniconism is the main distinctive feature of the late mosaics, not only these ones of the Douro, a taste for the formal complexity and the entanglement, for some geometric compositions with clear textile modulation and variegated chromatic charge that anticipate future styles of Islamic art and pre-Romanesque art, without forgetting its close relationship with the Asturian painting of the $9^{\text {th }}$ and $10^{\text {th }}$ centuries (Schlunk - Berenguer 1957, passim) that uses the same cartons, almost always from outside the figurative representation. It would be too easy to reduce it to a purely economic question, a geometric mosaic is undoubtedly cheaper than a figurative one, but it would not be forgivable to link it to a certain Neo-Pythagorean esotericism. In the Meseta, in addition, the reassumption of the old indigenous aniconic traditions should reinforce this tendency that, beyond a passing fashion, expressed the profound changes that a society in transit towards the feudalization experienced.

Except some villae (Camarzana de Tera, Quintana del Marco, Quintanilla de la Cueza-Palencia) (García Guinea 2000: 221-301), with good presence of figurative themes, usually only a great mythological pavement presides over an aniconic complex (Almenara, La Olmeda, Cardeñajimeno, San Pedro del Arroyo, etc.) (Fig. 21), or all tapestries are geometric (Requejo, Valdanzo-Soria, Cuevas

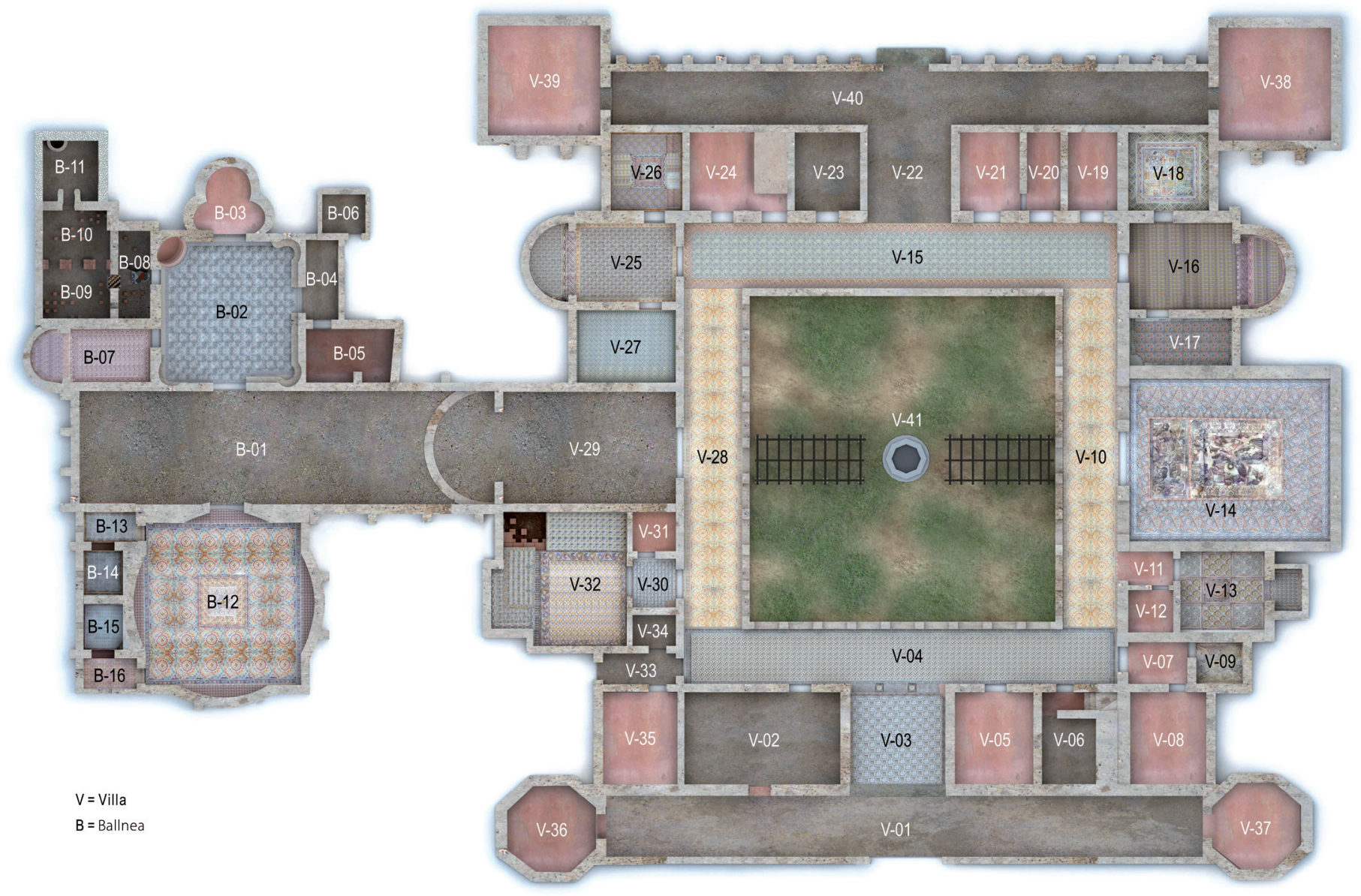



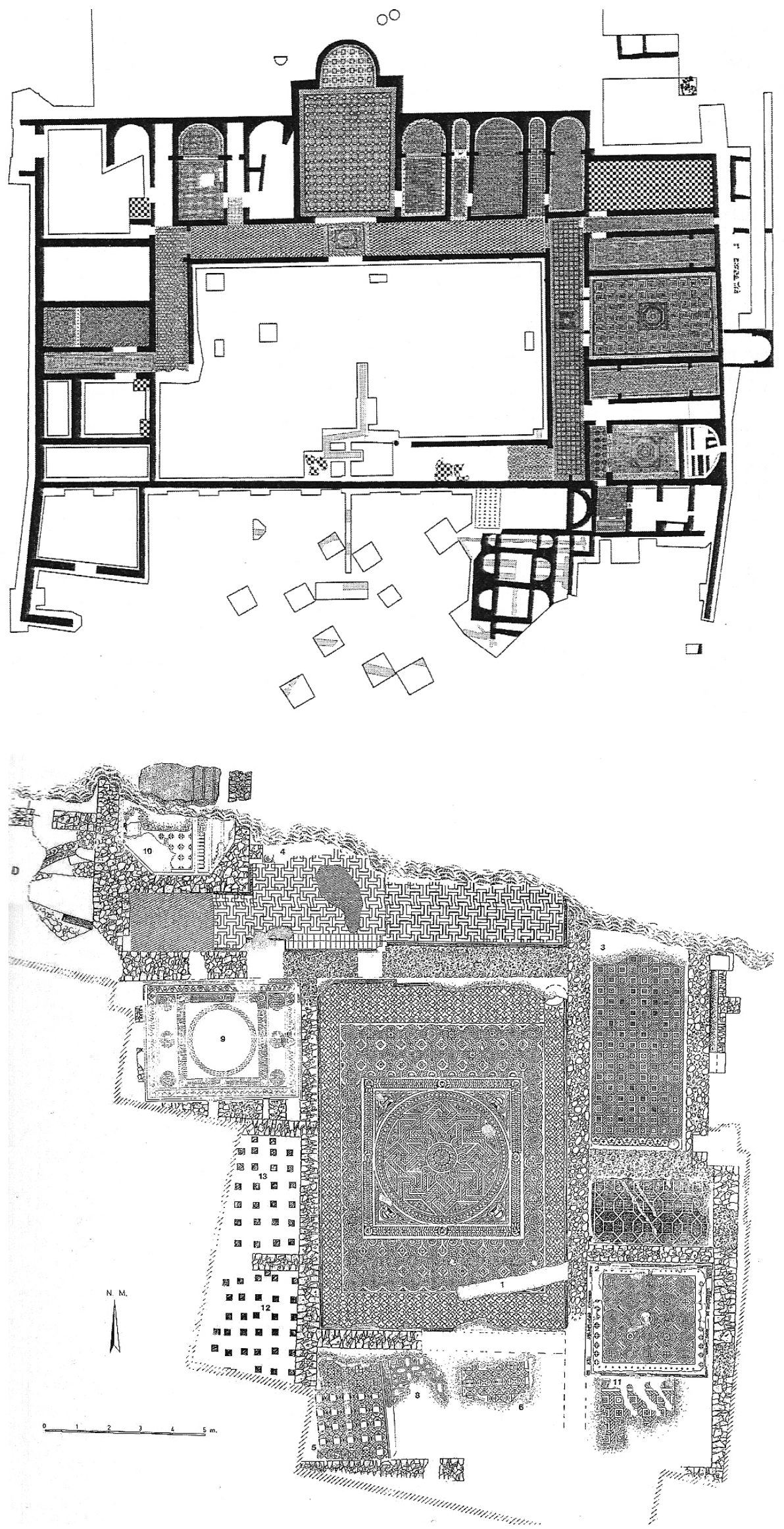

Figure 22a

General plan of Cuevas de Soria (Soria) with the mosaics. After Sanz Aragonés et al. 2011.
Figure 22b

General Plan of Requejo, (Santa Cristina de la Polvorosa, Zamora), with the mosaics. After Regueras Grande 1990. 
Figure 23

Meleager and the Calydonian boar. El Vergel, (San Pedro del Arroyo, Ávila). After Moreda - Serrano 2012

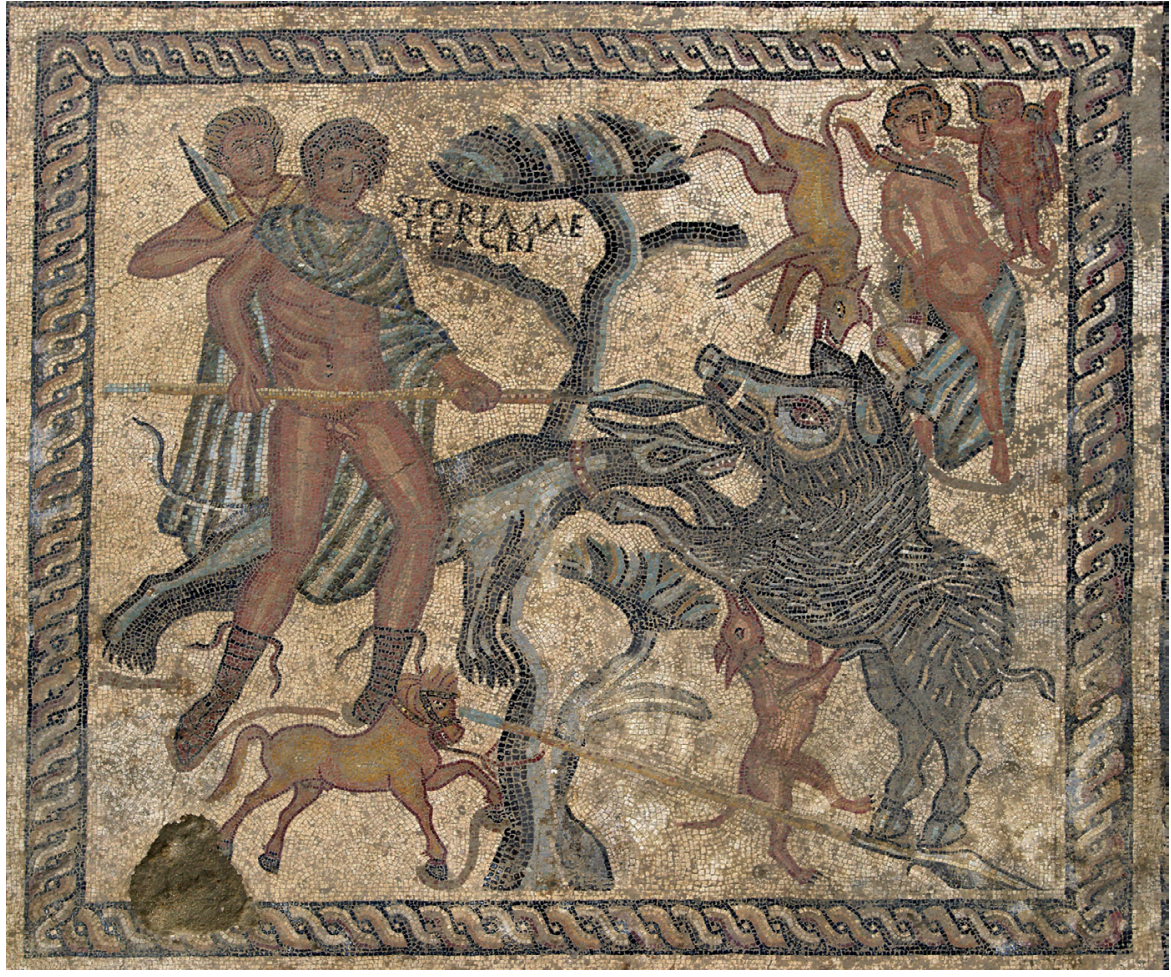

de Soria, etc.) (Fig. 22a-b). The imagery normally illustrates the function of the room: pelagic themes decorate balnea (Oceanos of Dueñas and Quintanilla de la Cueza, both in Palencia); the most versatile mythological themes, we find them mostly in oecus and triclinia, sometimes with explanatory epigraphs (Storia Meleagri of San Pedro del Arroyo, Bellerophon in equo Pegaso occidit Chimera, Ucero, Soria) (Fig. 23); others, bilingual, as the struggle of Glaucus and Diomedes of the Iliad in Cabezón de Pisuerga (Valladolid) (Neira - Mañanes 1989: 36-46).

It has been emphasised a lot in orientalism (Fernández Galiano 1984a: 411-430, Blázquez 2008: 7-31). The aniconic taste and the formal and decorative complexity of many of our mosaics (mosaic C de Baños de Valdearados, aula XII of Santervás, mosaic of the pitchers and the kraters of Prado) are even ascribed to it. This orientalism must be placed in the context of the Theodosian period that strongly influenced the late imperial elites of the Meseta. The use of more than 20 different types of marbles, mainly oriental and the use of mother-ofpearl in the villa of Las Pizarras (Coca, Segovia), establishes an unquestionable relationship with the $\mathrm{E}$ of the Mediterranean sea (such as the mosaics of Noheda-Cuenca-, the ones of Carranque-Toledo-, or the mosaic of Las Vegas mausoleum of Pueblanueva -Toledo-, in the Meseta Sur). It seems logical to also assign oriental features to the Latin and Greek epigraphs of the Iliad in Cabezón de Pisuerga (Valladolid) with the image of Glaucus and Diomedes, unicum in the Roman mosaic art that has served to interpret another one of Rielves (Toledo) known only by an $18^{\text {th }}$-century watercolour (Fig. 24a and b). However, some style coincidences are less certain, coincidences with the "oriental way" of fan-shaped or "scaly" backgrounds that are recognized in the most sumptuous mosaics with mythological episodes and hunting scenes, always in the second half of the $4^{\text {th }}$ century. Although there are splendid later specimens in Antioch or Constantinople (Imperial Palace) and exceptionally in Utica, Carthage or Colony, their maximum development occurs in the villae of the Hispanic Meseta 


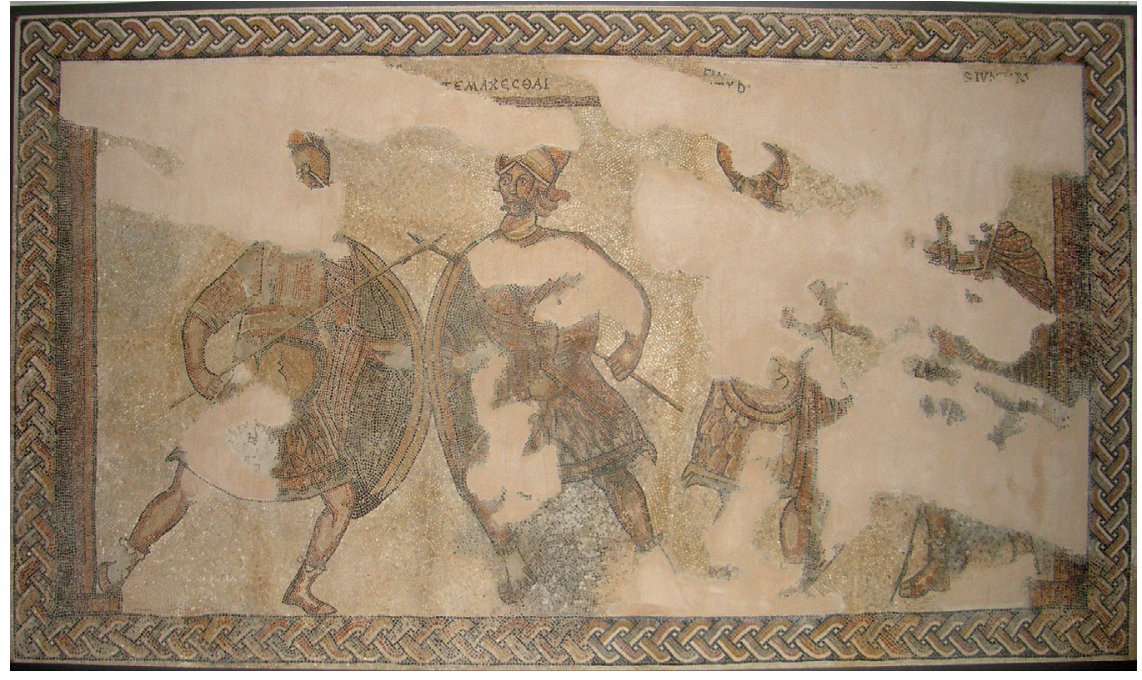

(Camarzana, Cardeñajimeno, La Olmeda, Quintana del Marco, Carranque, Noheda, Cabezón, Almenara, Saelices, etc.) with peripheral finds in Lusitania (Torre de Palma -Monforte, Portalegre-, El Hinojal-Las Tiendas, Badajoz-, Rabaçal-Condeixa a Nova, Coimbra-, etc), Ebro Valley (La Malena, Zaragoza) and now also in Lugo (mosaic of Daedalus and Pasiphaë) and the Dionysian cortège of Coriscada (Meda, Guarda). Other "oriental" features are the populated scrolls on a black background with vegetal Fig.s, "grutesques" (Cardeñajimeno, Camarzana), or putti cacciatori like that of Quintana del Marco (Fig. 25) and, above all, the representation of allegorical images embodied in the form of female busts: the Abundantiae of the workshops of Soria (Santervás, Rioseco, Medinaceli), which extends to the Iscallis of the villa of Saucedo (Talavera de la Reina, Toledo) at the end of the $5^{\text {th }}$ century.

With regard to the officinae that acted in a territory as wide as the Meseta, for more than a century, and about such a large number of mosaics, most of them not properly studied, only approximations, "selective affinities" based in stylistic criteria or in the use of "rare" materials (variscita). Without chronological

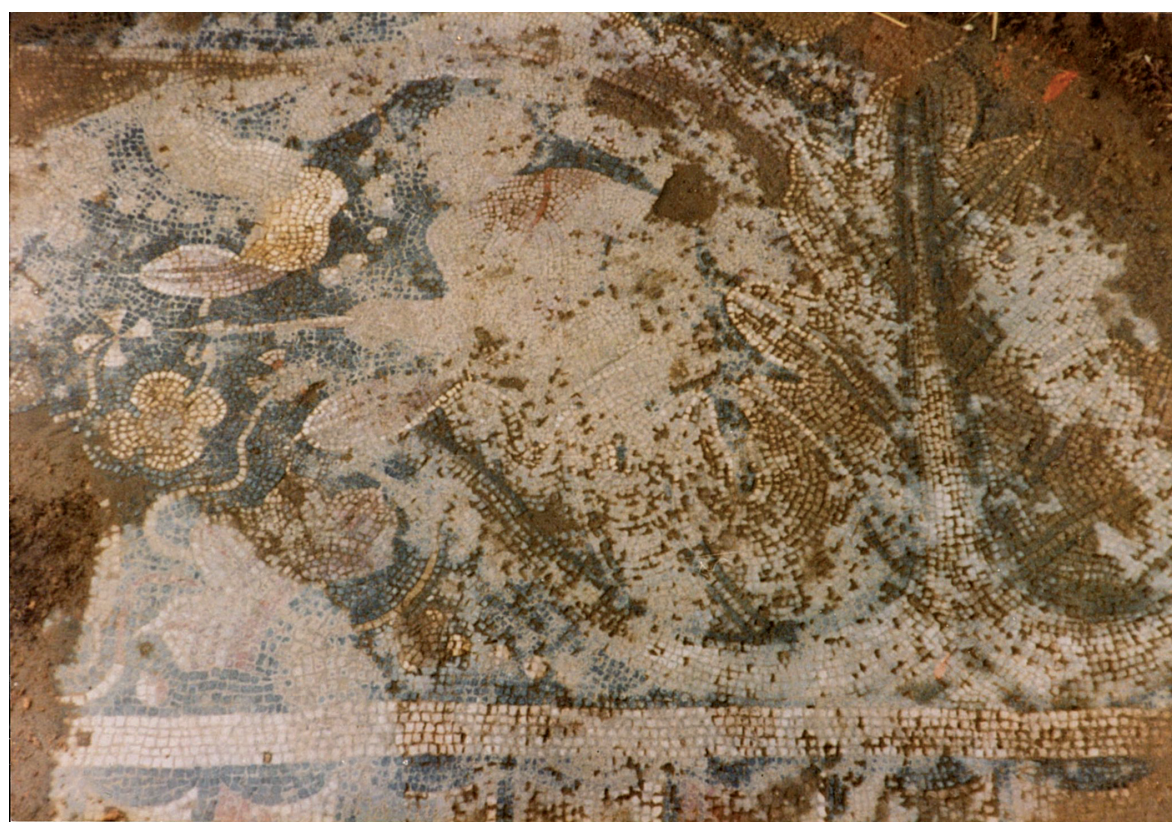

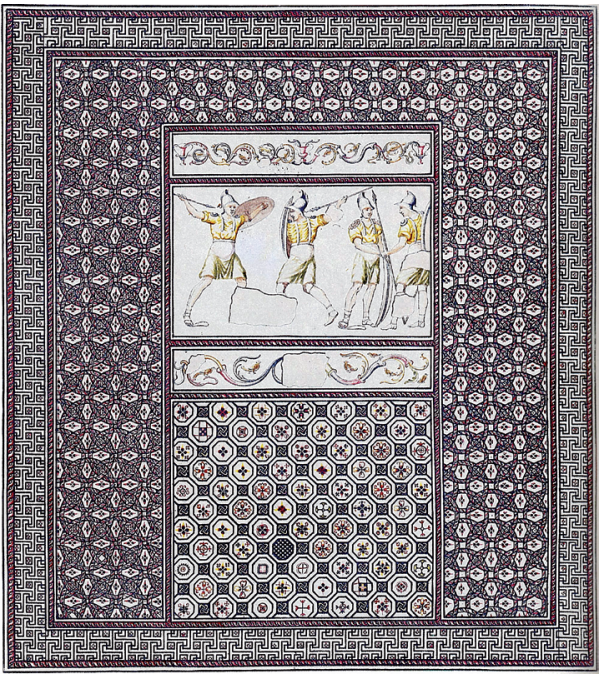

Figure 24a

Glaucus and Diomedes. (Cabezón de Pisuerga, Valladolid). After Mañanes.

Figure $24 \mathrm{~b}$

Glaucus and Diomedes. Rielves (Toledo). Watercolour of the XVIII century.
Figure 25 Putto cacciatore of Quintana del Marco (León). 
Figure 26

Horizontal stratigraphic. Room no. V-32 of La Olmeda (Palencia). Courtesy of Diputación de Palencia.

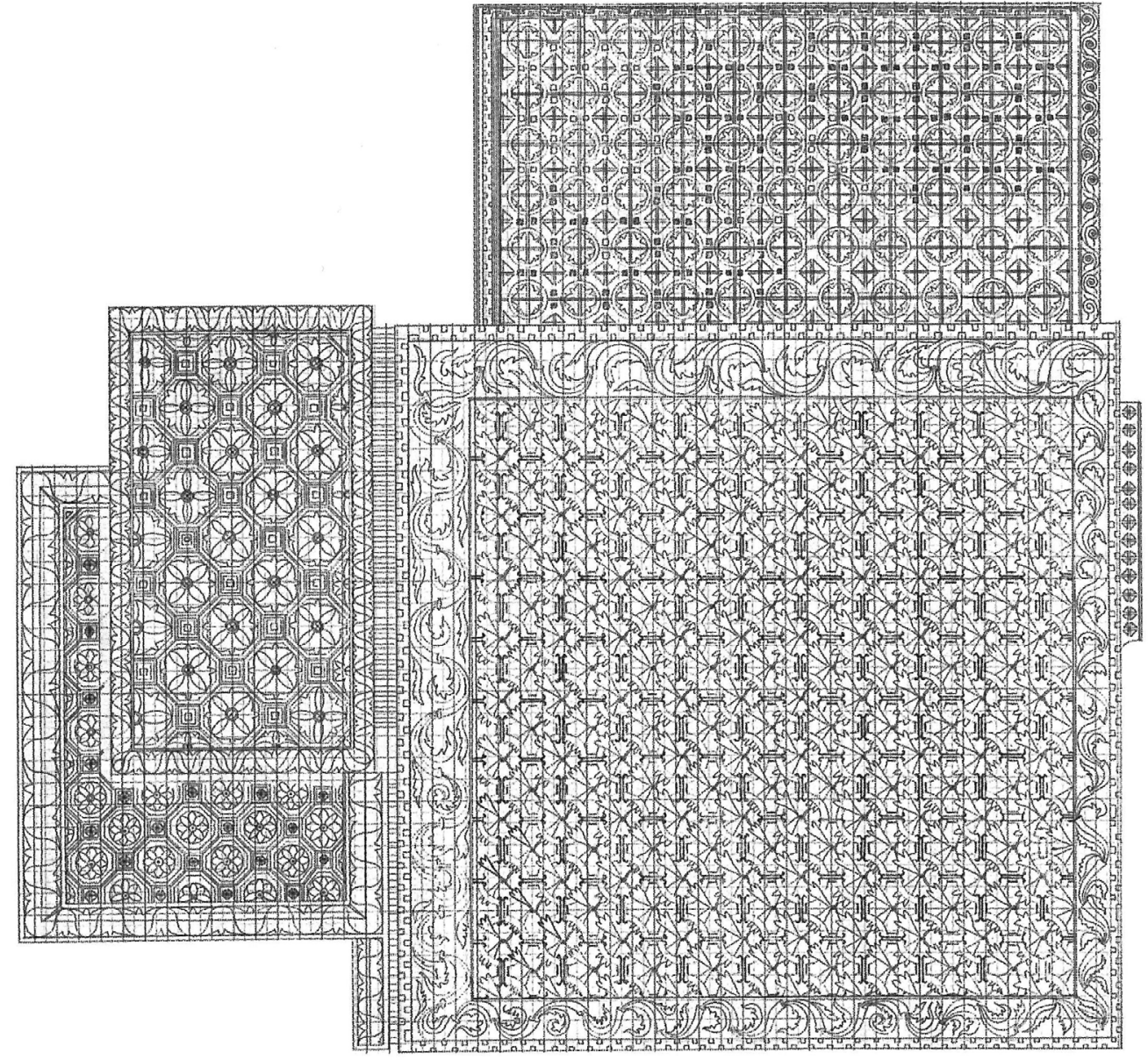

precisions it is very difficult to establish the existence of officinae. In any case, it is possible to prove analogies between many of our mosaics and centrifugal relations with the workshops of the peninsular NW and the southern Meseta, which in reality form a single community in the use of schemes, taste and style.

Firstly, La Olmeda is the best excavated and well-known villa in the Iberian Peninsula, with mosaics from two floors, and with vertical and horizontal mosaic stratigraphies (Fig. 26). About the 14 known mosaic firms throughout Hispania, only one is registered in Castilla y León, at a corner of the great room with four apses of the baths of La Olmeda (Pedrosa de la Vega, Palencia), a SIL [O] (Fig. 27), we do not know if one of the tessellarii of the carpet of braids and interlaced garlands; by the way, its design is the richest and the most widespread in the house: external border of oecus, the east and west gallery of the peristyle, the room of balneum with four apses and apodyterium, sealed by a caementicium pavement and above another tessellatum of octagons, with poor elaboration). If so, presumably at least two other workshops would exist in the villa, the one in charge of the figurative ensemble (Fig. 28) and another one of the later simpler mosaics (as the above-mentioned one of octagons). In Carranque it is verified the presence of two officinae, an extension in space and a mosaic complexity less than in La Olmeda. Several tesserae deposits (V-13, V-21, under the south gallery of the peristyle), tesserae and glass cakes -some of them with gold foilshave been documented in the V-35, for mosaics never made or perhaps to cover the irremediable repairs of the house, which would presuppose the existence of a fixed officina of the maintenance In this deposit, it is also known with sufficient precision where they extracted the calcareous material to build their mosaics, 
a place in the Cantabrian range between Alar del Rey and Aguilar de Campoo (Palencia), the gray marble of some rooms (V-14 and V-09), from the quarry of Velilla del Río Carrión (Palencia), slightly more than $30 \mathrm{~km}$ to the $\mathrm{N}$, and in the oecus, some reused marble tesserae come from Espejón (Soria). Underneath this pavement there were many defective pieces and tesserae, a customary circumstance in mosaics of other villae (Requejo, Valdanzo). The raising and restoration of all the mosaics of the villa allowed to verify the existence of underlying sinopias that outline the main lines of these mosaics; and the documentation of three coins of Constantine (307-337) and his son Constans (337-350) served to establish a terminus post quem of the corresponding mosaics. Thanks to these data and to the careful monitoring of the villa -which has been continuously excavated since 1968- an absolute chronology of its mosaics can be determined between the second half of the $4^{\text {th }}$ century and the first half of $5^{\text {th }}$ century.

Another similar deposit, with reused tesserae from a $3^{\text {rd }}$-century pavement, was located in the nearby villa de Los Moros (La Serna, Palencia), a procedure, widely documented in villae: the Villa de la Estación (Antequera, Málaga), in Betica; those ones of Rio Maior (Santarem) and Rabaçal, to cite two Portuguese examples (Vargas Vázquez - López Monteagudo 2014: 127-142).

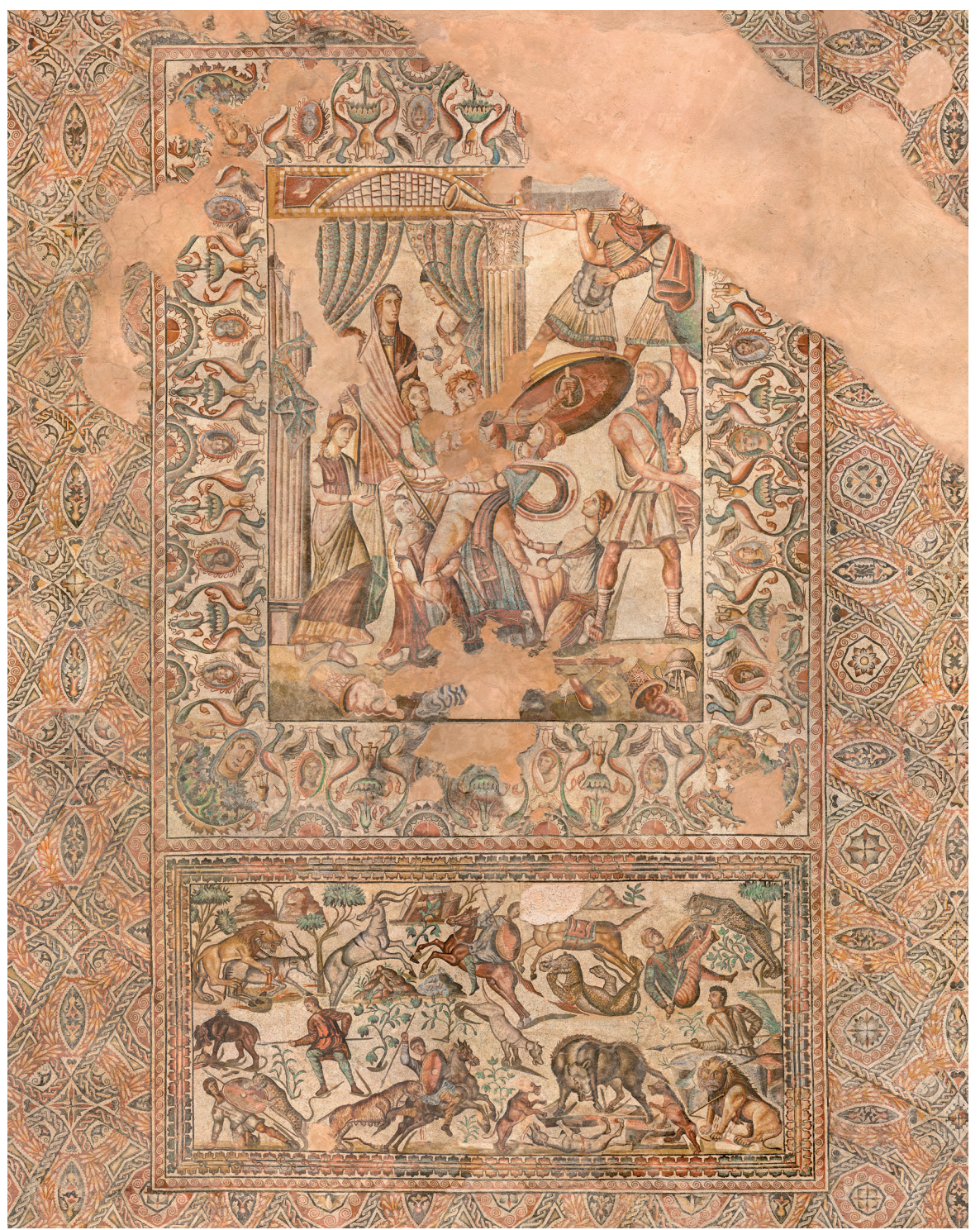

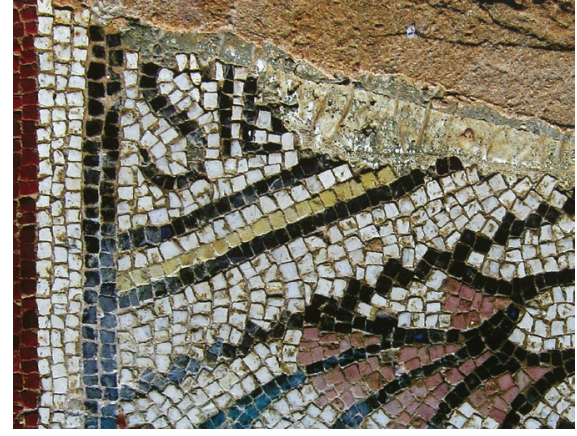

Figure 27 $S I L[\mathrm{O}]$, perhaps a tessellarius of La Olmeda.
Figure 28

Oecus of La Olmeda. Mosaic of Achilles in Skyros and scene of venationes. 


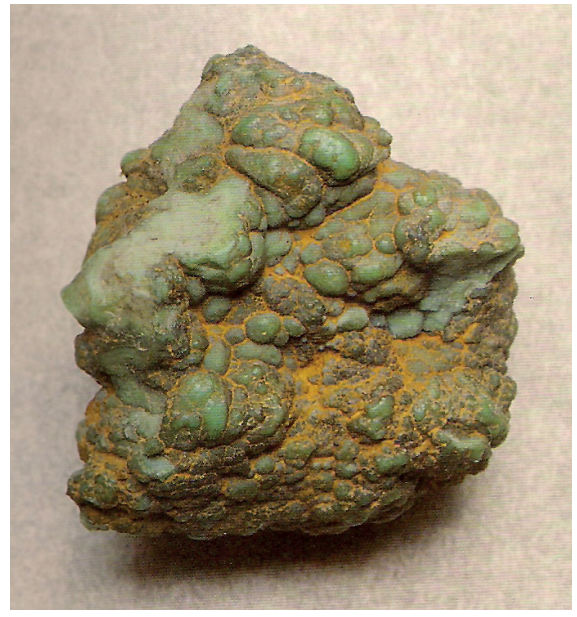

Figure 29a

Variscite from the villa of Quintana del Marco (León).

Figure 29b

Oceanos mosaic from the frigidarium of the villa of Dueñas (Palencia).

\section{Figure 30a}

Mosaic of the peristyle (detail).

La Valmuza (Salamanca).

\section{Figure 30b}

Mosaic of Alcázar de San Juan (Ciudad Real).

Figure 30c

Mosaic of the peristyle (detail).

La Valmuza (Salamanca).

\section{Figure 30d}

Mosaic of Alcázar de San Juan (Ciudad Real).

\section{Figure 30e}

Mosaic of the peristyle (detail). La Valmuza (Salamanca).

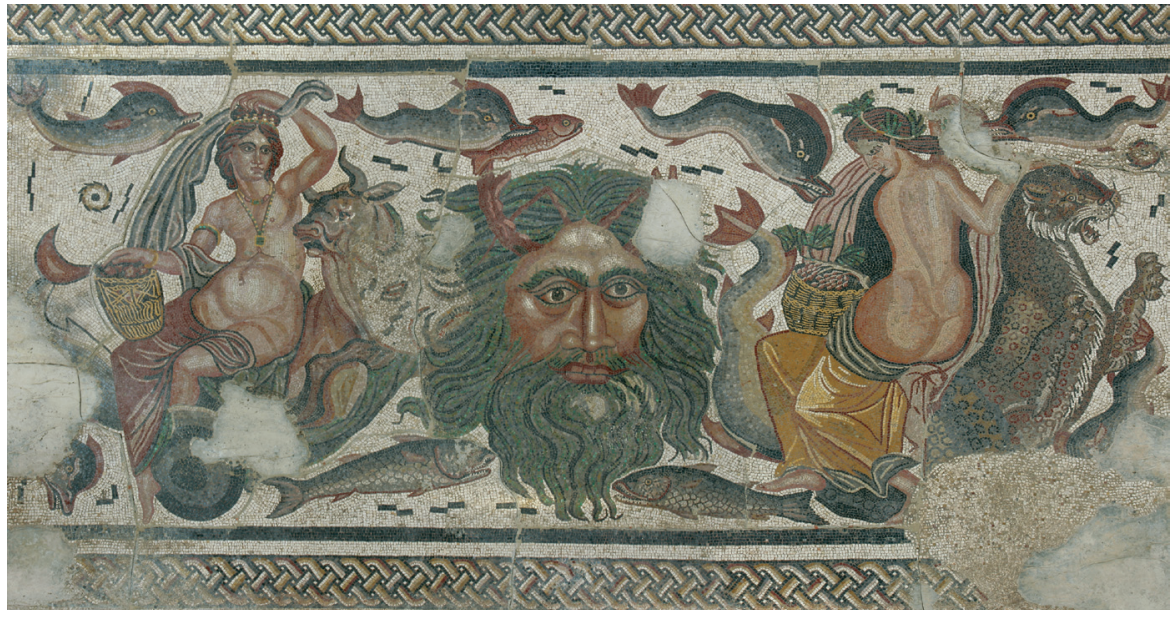

On the basis of a recent multidisciplinary study about materials (Gutiérrez Pérez et al. 2015: 165-181), it has been possible to determine the precise origin (Palazuelos de las Cuevas, Zamora) of variscite, a semiprecious stone whose use in the Late Roman Empire was almost exclusively restricted to the manufacture of tesserae (Fig. 29a-b) of the most beautiful mosaics of the Roman villae: Possidica of Dueñas (Palencia), Quintana del Marco (León), and although it was not analysed, almost certainly, the ones of Camarzana de Tera (Zamora), all of them already associated by stylistic and iconographic traits in common. This use of an unusual material could imply the existence of an itinerant workshop in these villae where it was assumed (Quintana del Marco) that another officinal would work, called by M. Torres Prado-Almenara, because of his intervention in these villae of Valladolid (Torres Carro 2011: 41-52).

This officina likes vegetal themes -really scarce in the Meseta- on neutral or dark backgrounds: garlands that start from kraters with segments, flowers of very thin stem in the form of a little bell that leave of the vegetal horn of the scroll associated with rounded fruits. They are subjects and forms that are traced in the villae of Prado, Quintana del Marco, Navatejera (León), Cabezón de Pisuerga and also in the $\mathrm{N}$ and $\mathrm{S}$ arms of the cruciform aula of Pegasus of La Valmuza (Salamanca) (Regueras Grande - Pérez Olmedo 1997: 15-40). It is a territory where there is an interest in vegetal weaving in the old descriptions of the mosaics of Cabrillas and Castañeda de Tormes, both in Salamanca). The study of the tapestries of this villa of La Valmuza makes it possible to distinguish another officina (or group of skilled artisans within the same workshop) who worked in the SE area of the peristyle, and whose schemes and decorative forms are identical (Fig. 30a-e) to the mosaics of Alcázar de San Juan (Ciudad Real). The first officina (Prado-Almenara) would intervene mainly in Almenara
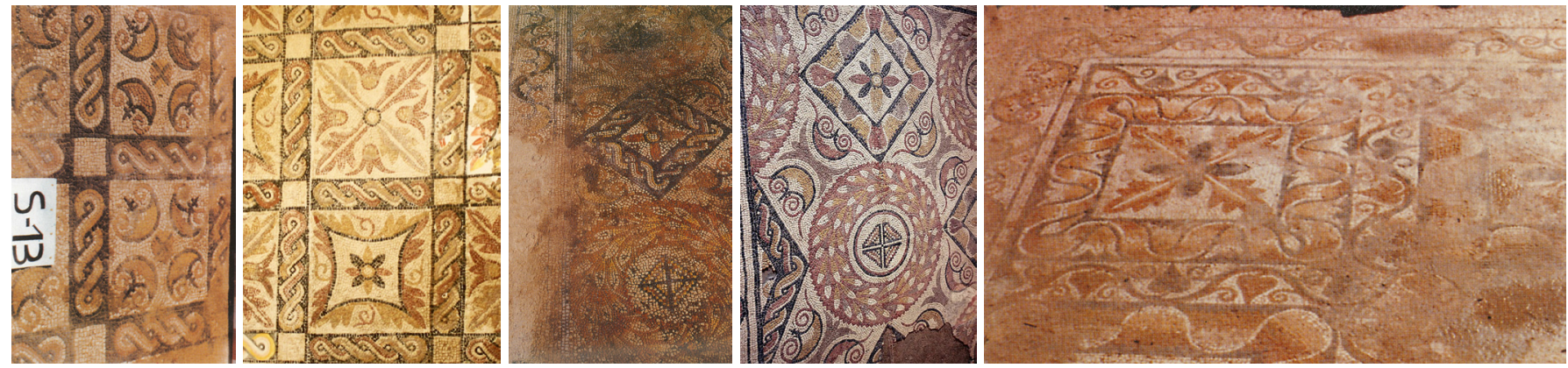
de Adaja where, as in La Valmuza, the theme of Pegasus and the Nymphs is also recorded, exclusive iconography of both villae inside Hispania, although its composition is different; The second officina, in Alcázar de San Juan and other villae of the Meseta Sur, for a long time associated with the work of the same itinerant workshop, among them the one of Gárgoles (Guadalajara), in which there is a cruciform aula, almost identical to the aula of La Valmuza.

This archaeological unit between the Douro Basin and the Tagus Basin, which form part of what we could call the "Theodosian historical nucleus", can also be seen in the relationship between the mosaics of Segovia (in the Meseta Norte) and the ones of Complutum (in the Meseta Sur): that one of the room with the Seasons of Paradinas presents a compositional organization apparently similar to that of Bacchus of Complutum whose iconography resounds in the description of Martín Sedeño, at the end of the $18^{\text {th }}$ century, about the disappeared mosaic of the grape harvest of Los Mercados (Duratón). The so-called "red mosaic" of Complutum (Alcalá de Henares, Madrid) shows the same chromatic containment and linear treatment as the geometric carpet of the oecus of Aguilafuente, in line with aesthetics of the end of the $4^{\text {th }}$ and $5^{\text {th }}$ centuries. Relationships between the two Mesetas that Fernández Galiano wanted to extend to the villa of Quintanilla de la Cueza (mosaics of Leda, Bacchus and Cupids). (Fernández Galiano 1984b: 186).

This movement of the officinae is also reflected, as we pointed out, in a repertoire of images such as the scenes of the Iliad of Cabezón (Valladolid) and Rielves (Toledo), and above all in the busts of allegories that preside some of the most emblematic spaces of the east and west arms of the aula trichora of Los Quintanares (Rioseco de Soria, Soria), decorated with a mesh of hexagons and vermiculated central emblems, also with hexagonal form, only preserved the one of the western side with representation of Abundantia (or Fortuna) carrying plate and cornucopia (Fig. 31); in Santervás del Burgo (Fig. 32), in the middle of the oval room with rich carpet of complex geometric design, with image of Ceres, also with cornucopia and flabellum, inscribed in a frame of two squares that are crossed diagonally. It is possible that the mosaic B of Baños de Valdearados that carries the same rotating squares in the centre could have housed an allegory like that of Santervás. Also in the mosaic of the Plaza Mayor of Medinaceli (Fig. 33) a mosaic of triclinium was documented and its central part was occupied by a standing image of Ceres/Abundantia with the cornucopia, surrounded by representations of the winds, being identical in their formal coarseness to that one of Santervás. On the other side of the mountains we know two busts in the villa of Saucedo (Toledo): the first of them is of Iseaius, who
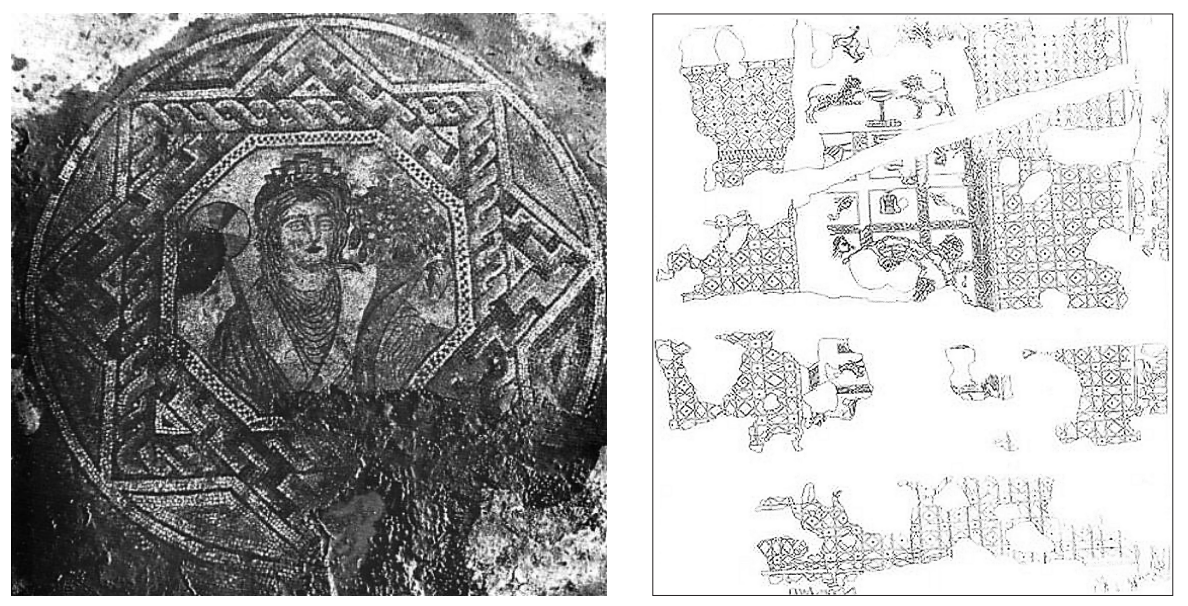

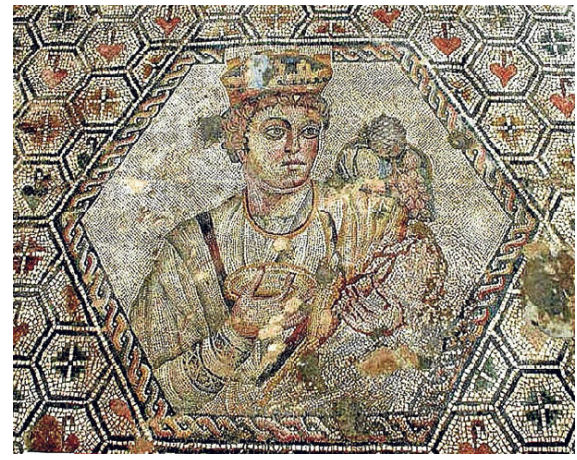

Figure 31 Feminine bust of Rioseco de Soria (Soria).
Figure 32

Feminine bust of Santervás del Burgo (Soria).

Figure 33

Mosaic of the Plaza Mayor of Medinaceli (Soria), after Borobio - Pascual 1998 


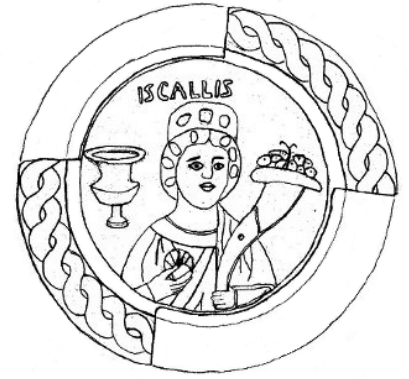

Figure 34

Iscalis of Saucedo

(Talavera de la Reina, Toledo).
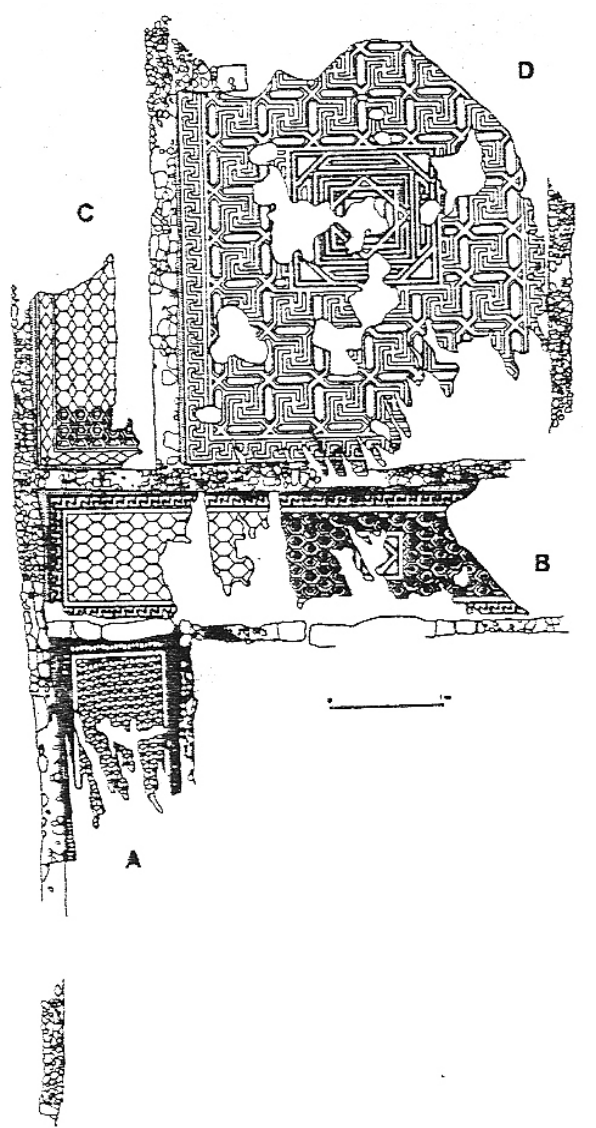

Figure 35

Oecus of Valdanzo (Soria), after Jimeno, Argente and Gómez 1988-1989. wears a tunic and a bonnet of Pannonia, inscribed in a tondo in a mosaic with the known scheme of squares and circles, and holds cornucopia with the left hand, under which a fish goes, and an apple with the other hand; the second bust is of Iscalis, a matron dressed in a robe and mantle, carrying a cornucopia and a globe (Fig. 34), symbols of Fortuna or Tyche, in the of a Christian basilica at the end of the $5^{\text {th }}$ century, built on the site of an old thermal space. This taste for supplanting mythological compositions by other allegorical or symbolic embodied abstractions is the fashion of the Late Roman Empire, as D. Levi pointed out for the mosaics of Antioch.

Finally we will refer to a workshop that D. Fernández Galiano called CuevasValdanzo (Fernández Galiano 1980b: 127-137), because of the close affinity between the two villae of Soria. They are pavements of great ornamental intensity that take advantage of a simple and universal repertoire of geometric schemes and themes and also of a restricted chromatic palette (four colours). In spite of this they show a great compositional complexity that required preparatory designs and a technical knowledge previously defined by sinopias, or incisions, that guided the execution of the tapestry. A relevant feature of this officina is the development of squares, with inscribed circles, or crossed obliquely generating octagons, as emblems on the field of mosaic, markers of the distinction of the room or pointing, at other times, the access to them in the mosaic of the peristyle (Fig. 35). This complex treatment of the geometric themes, with concentric compositions, very overloaded and baroque compositions of textile modulation, turns some of our mosaics into authentic "oriental carpets" avant la lettre. Even the aforementioned squares rotated 45 degrees that give rise to an eight-pointed star suggest whether there would be no prophylactic interest in the development of this system, which will then retain all its magical value in the arts of Islam.

Beyond the relationship between the two villae (Cuevas-Valdanzo) and others of Soria such as Rioseco, Santervás and Ucero, others of Toledo as Rielves and others of the Ebro Basin, with dozens of geometric mosaics of the same tenor, we must understand the Cuevas-Valdanzo officina as a sort of "transverse phenomenon "that affects a good part of the peninsular interior area, especially the Mesetas), with different groups or teams working on common variables. That is, the wording of all these mosaics indicates above all the circulation of a standardised koiné that, for different reasons attracted many late Roman owners, being applied with different accents. Perhaps it is no coincidence that there is a close proximity between the centred scheme of the oecus of Valdanzo, the triclinium to the East of Cuevas, and the great mosaic no. 1 of the villa of Requejo, at the other end of the Castilian Meseta (Fig. 36a-b); or between the pool of the frigidarium of Requejo and the small bath of the caldarium of Cuevas. Nevertheless, although everyone shares this common feeling, for the moment, it is not possible to go further.

Other small officinae are detected in smaller areas, such as the one that worked in successive times in Cardeñajimeno, at the end of the $4^{\text {th }}$ century and already in the $5^{\text {th }}$ century in Baños de Valdearados, both in the province of Burgos; in Quintanilla de la Cueza and La Olmeda, or the group that intervened in villae of Ávila like Magazos, possibly Mancera (Ávila) and especially in San Pedro del Arroyo (Fig. 37a-b). Here we find an old scheme (El Picadero, Écija, in the $2^{\text {nd }}$ century), reformulated in the $4^{\text {th }}$ century in four villae of the Meseta: San Pedro del Arroyo, (Ávila), Guijar de Valdevacas (Segovia), Prado (Valladolid) and Villasirga (Palencia), to the extent that it seems work of the same mosaicists (Fig. 38a-d). 


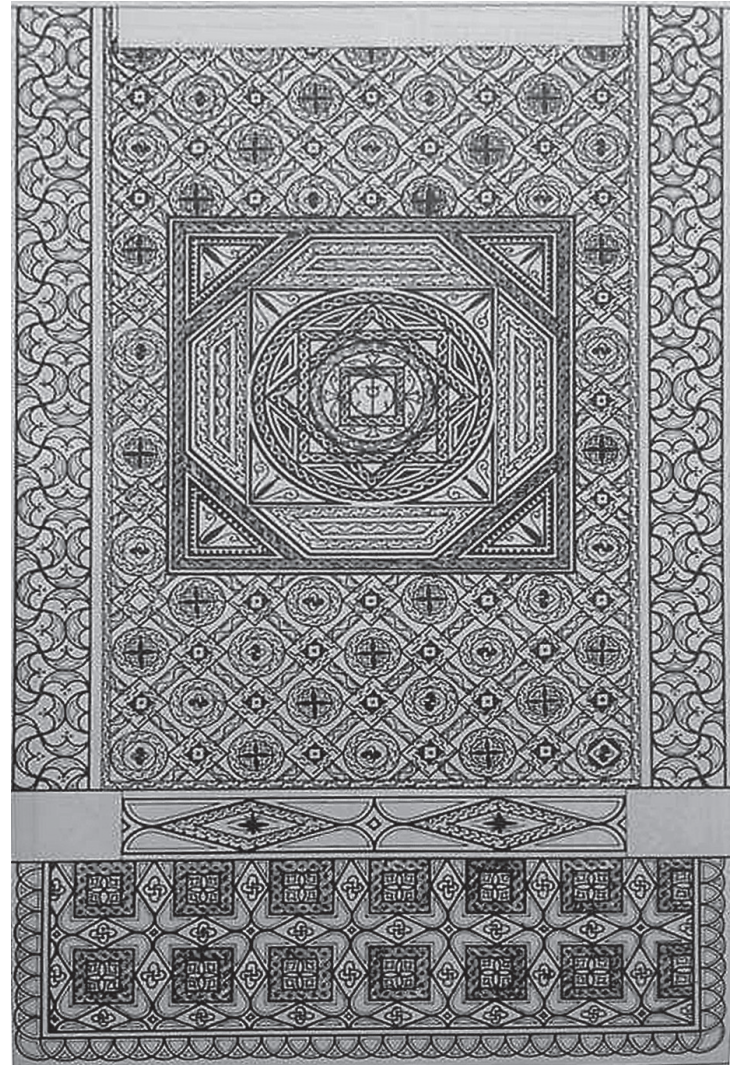

a

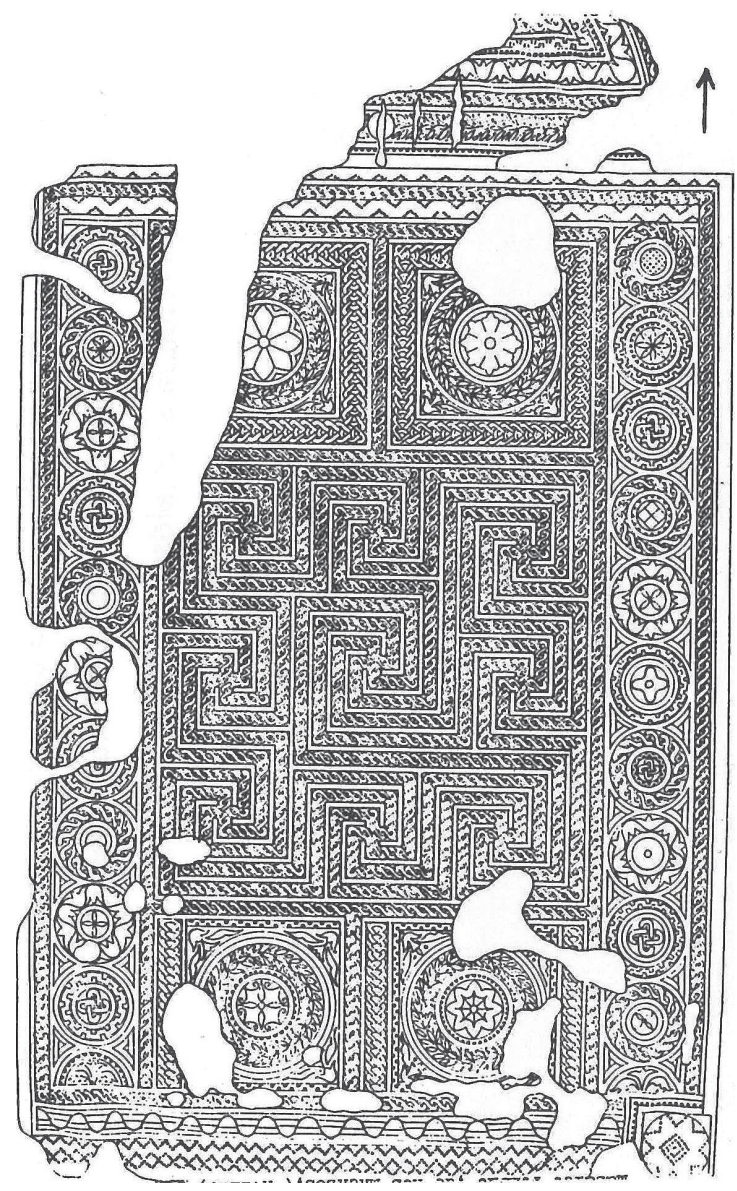

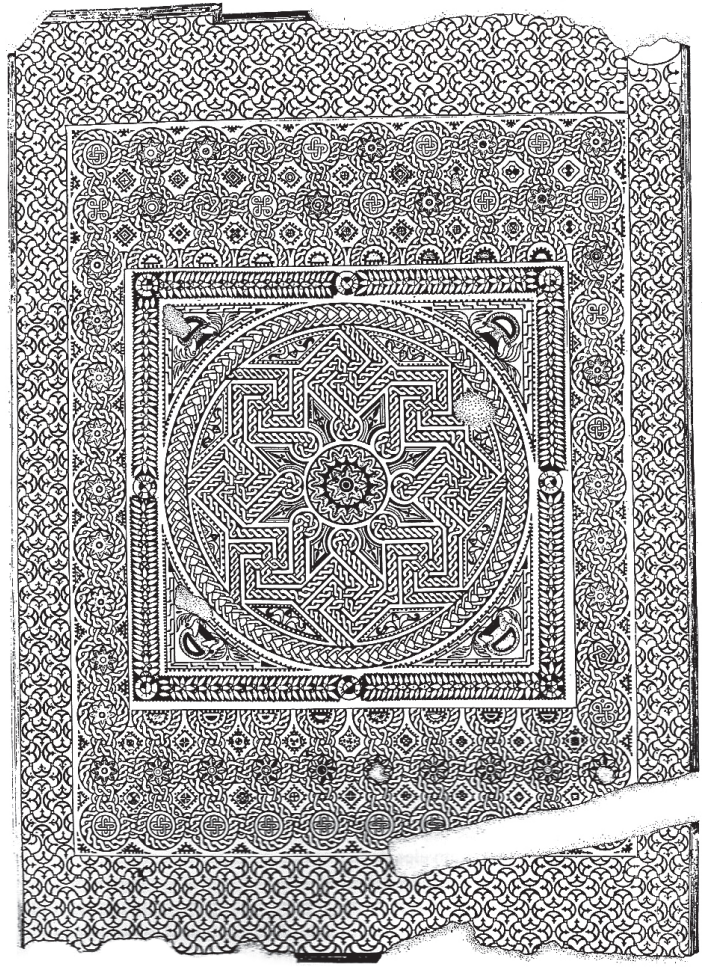

Figure 36a

Triclinium of Cuevas de Soria (Soria).

Figure $36 \mathrm{~b}$

Mosaic no. 1

of Requejo

(Santa Cristina de la

Polvorosa, Zamora), after Regueras Grande 1990

Figure 37a

Mosaic of Magazos

(Ávila),

after Museo

de Ávila.

Figure 37b

Mosaic of El Vergel

(San Pedro del

Arroyo, Ávila), after Moreda Serrano 2012. 
Figure 38a

Room no. 7. San Pedro del Arroyo

(Ávila), after Moreda - Serrano 2012.

Figure 38b

Mosaic of La Palatina

(Guijar de Valdevacas, Segovia).

Figure 38c

Mosaic of villa de Prado (Valladolid).

Figure 38d

Mosaic of Villasirga (Palencia).

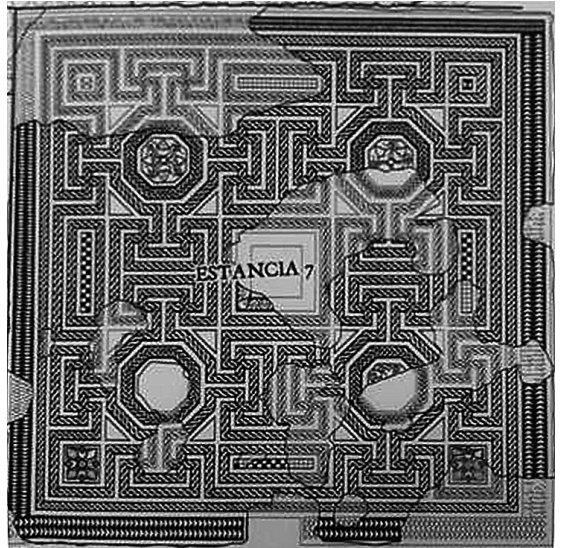

a

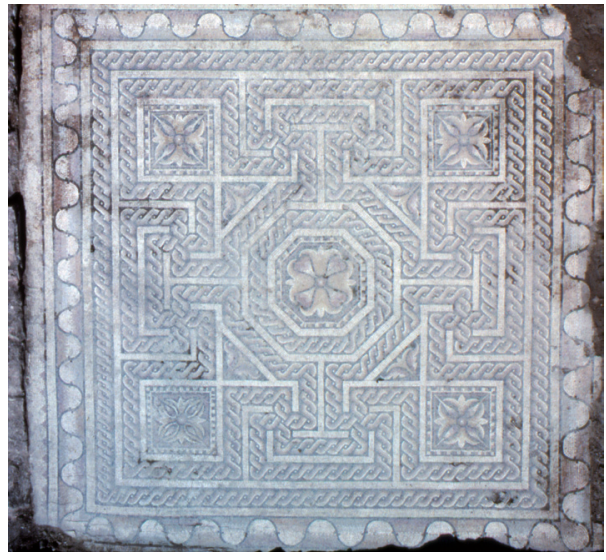

b
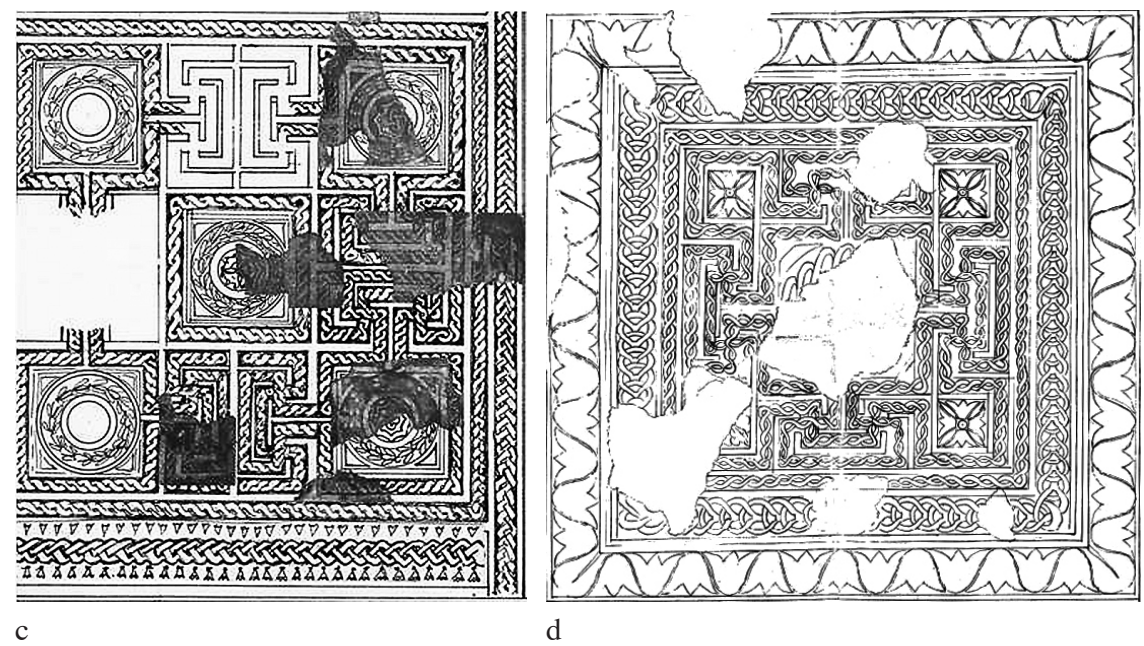

$\mathrm{d}$

\section{Bibliography - Kaynaklar}

Abásolo 2013

Argente et al. 1990

Blázquez et al. 1998a

Blázquez et al. 1998b

Blázquez - Ortego 1983

Blázquez 2008

Borobio - Pascual 1998

Cortes Álvarez de Miranda 1996

J. Cortes Álvarez de Miranda, Rutas y villas romanas de Palencia, Diputación de Palencia, Palencia.

Décor I

C. Balmelle - M. Blanchard Lemée - J. Christophe - J. P. Darmon - A. M. Guimier Sorbets - H. Lavagne R. Prudhomme - H. Stern, Le Décor Géométrique de la Mosaïque Romaine I, Paris, Picard, 1985.

Fernández Galiano 1980a
J. A. Abásolo, Los mosaicos de la Olmeda. Lujo y ostentación en una villa romana, Diputación de Palencia, Palencia.

J. L. Argente - A. Díaz - A. Bescós, Tiermes. Excavaciones arqueológicas. Campaña 1990, Junta de Castilla y León: 35-42.

J. M. Blázquez - G. L. Monteagudo - T. Mañanes - C. F. Ochoa, Mosaicos Romanos de León y Asturias, Corpus de Mosaicos de España X, Madrid, Consejo Superior de Investigaciones Científicas.

J. M. Blázquez - G. L. Monteagudo - M. L. Neira - M. P. San Nicolás, Mosaicos Romanos del Museo Arqueológico Nacional, Corpus de Mosaicos de España IX, Madrid, Consejo Superior de Investigaciones Científicas.

J. M. Blázquez - T. Ortego, Mosaicos Romanos de Soria, Corpus de Mosaicos de España VI, Madrid, Consejo Superior de Investigaciones Científicas.

J. M. Blázquez, "Der Einfluss der Mosaiken des vorderen Orients aufhispanische Mosaikenam Ende der Antike", JMR 1-2, 7-31.

M. J. Borobio - A. C. Pascual, "Mosaicos romanos de Medinaceli”, Revista de Soria 21, Soria, 39-45. 
Fernández Galiano 1980b

Fernández Galiano 1984a

Fernández Galiano 1984b

García Guinea 2000

García Merino - Sánchez Simón 2015

C. García Merino - M. Sánchez Simón, La villa romana de Almenara de Adaja-Puras a través de los archivos del tiempo, Valladolid.

Gómez de Somorrostro 1820

A. Gómez de Somorrostro, El acueducto y otras antigüedades de Segovia, Madrid, 215-225.

Gutiérrez Pérez et al. 2015

Jimeno et al. 1988-1989

López Monteagudo et al. 1998 G. López Monteagudo - R. Navarro Sáez - P. de Palol Salellas, Mosaicos Romanos de Burgos, Corpus de Mosaicos de España XII, Madrid, Consejo Superior de Investigaciones Científicas.

Lucas - Viñas 1977

Mariné 1995

Martínez - Vilches 2015

Moreda - Serrano 2012

Neira - Mañanes 1989

Palol Salellas 1963

Pérez González 1987

Regueras Grande - Pérez Olmedo 1997

Regueras Grande 1990

Regueras Grande 2002

Regueras Grande 2007

Regueras Grande 2009

Regueras Grande 2012

Regueras Grande 2013

Regueras Grande 2015
F. Regueras Grande - E. Pérez Olmedo, Mosaicos romanos de la provincia de Salamanca. Monografías. Arqueología en Castilla y León 2, Junta de Castilla y León, Salamanca.

R. Lucas - V. Viñas, "La villa romana de Aguilafuente (Segovia)", Segovia. Symposium de Arqueología romana, Barcelona: 239-255.

M. Mariné, “La época romana”, M. Mariné (coord.). Historia de Ávila I. Prehistoria e Historia Antigua, 2a ed., Ávila 1998: 321-328.

S. Martínez - S. Vilches (coords.), Imago Urbis Romae. Ciudades de Segovia, Museo de Segovia.

F. J. Moreda - R. Serrano, "El mosaico de Meleagro de la villa romana de El Vergel en San Pedro del Arroyo", C. Fernández - R. Bohigas (eds.), In Durii Regione Romanitas. Estudios sobre la presencia romana en el valle del Duero en homenaje a Javier Cortes Álvarez de Miranda, Palencia/Santander: 337-342.

M. L. Neira - T. Mañanes, Mosaicos Romanos de Valladolid, Corpus de Mosaicos de España XI, Madrid, Consejo Superior de Investigaciones Científicas.

P. de Palol Salellas, "El mosaico de tema oceánico de la villa de Dueñas (Palencia)”, BSAA XXIX, 5-34.

C. Pérez González, "Nuevos mosaicos procedentes de Villabermudo y noticias sobre otros asentamientos del norte palentino", Actas del I Congreso de Historia de Palencia I, Palencia, 463-484.

F. Regueras Grande, "Los mosaicos de la villa romana de Requejo (Santa Cristina de la Polvorosa)", Actas del Primer Congreso de Historia de Zamora, Tomo 2. Prehistoria-Mundo Antiguo, 637-696, Instituto de Estudios Zamoranos "Florián de Ocampo", Zamora.

F. Regueras Grande, "Mosaico", in M M $^{\mathrm{a}}$ T. Amaré (dirección), Astorga II. Escultura, glíptica y mosaico, Colección de Arqueología Leonesa. Serie Astorga II, Universidad de León, León, 37-11.

F. Regueras Grande, "Villas romanas del Duero: Historia y patrimonio", Brigecio 17, Centro de Estudios Benaventanos "Ledo del Pozo", 11-59.

F. Regueras Grande, Camarzana, pasado y presente de una villa romana del Tera, Ministerio de Cultura y Ayuntamiento de Camarzana de Tera, Salamanca.

F. Regueras Grande, "Villae tardorromanas en Segovia", in S. Martínez, J. Santiago and A. Zamora (coords.), Segovia Romana II. Gentes y territorios, Obra social y cultural de Caja Segovia, Segovia, 279-310.

F. Regueras Grande, Villas romanas del Duero. Historia de un paisaje olvidado, Valladolid, Domus Pucelae, 73-96.

F. Regueras Grande, "Mosaicos romanos del Conventus Asturum. Estado de la cuestión y encrucijada patrimonial", Actas Encuentro Portugal Galiza. Mosaicos romanos. Fragmentos de cultura nas proximidades do Atlántico, APECMA/AIEMA, 279-304. 
Sanz Aragonés et al. 2011

Schlunk - Berenguer 1957

Torres Carro 1990

Torres Carro 2011

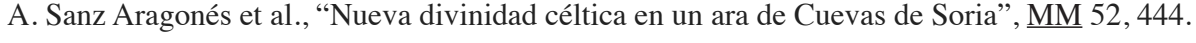

H. Schlunk - M. Berenguer, La pintura mural asturiana en los siglos IX y X, Oviedo.

M. Torres Carro, "Los mosaicos de la Meseta Norte”, BSAA LVI, 223-243.

M. Torres Carro, "Corrientes artísticas y talleres tardíos en Hispania", O Mosaico Romano nos Centros e nas Periferias. Originalidade, influencias e identidades. Actas do X Coloquio Internacional da AIEMA, Conimbriga, 41-52.

Vargas Vázquez - López Monteagudo 2014

S. Vargas Vázquez - G. López Monteagudo, "Talleres musivos hispanorromanos. Formas de producción y áreas de dispersión" M. Bustamante - D. Bernal (coords.), Artífices idóneos. Artesanos, talleres y manufacturas en Hispania, 125-142. Instituto de Arqueología de Mérida, Mérida. 
